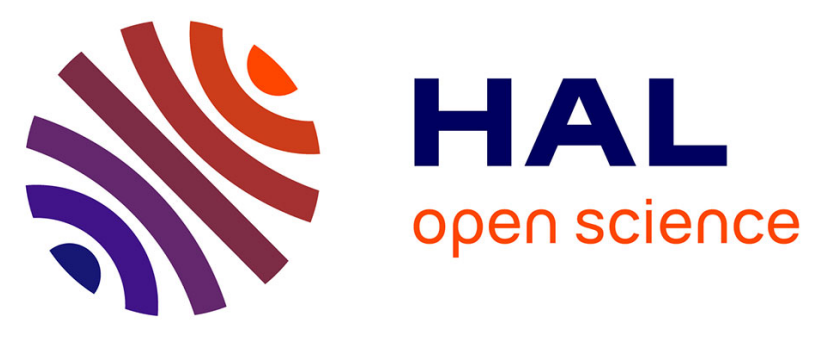

\title{
Modifications of the soluble proteome of a mediterranean strain of the invasive neurotoxic dinoflagellate Alexandrium catenella under metal stress conditions
}

\author{
Natacha Jean, Estelle Dumont, Faouzi Herzi, Thierry Balliau, Mohamed
}

Laabir, Estelle Masseret, Stéphane Mounier

\section{To cite this version:}

Natacha Jean, Estelle Dumont, Faouzi Herzi, Thierry Balliau, Mohamed Laabir, et al.. Modifications of the soluble proteome of a mediterranean strain of the invasive neurotoxic dinoflagellate Alexandrium catenella under metal stress conditions. Aquatic Toxicology, 2017, 188, pp.80-91. 10.1016/j.aquatox.2017.04.011 . hal-01569507v2

\section{HAL Id: hal-01569507 \\ https://hal.science/hal-01569507v2}

Submitted on 23 Sep 2018

HAL is a multi-disciplinary open access archive for the deposit and dissemination of scientific research documents, whether they are published or not. The documents may come from teaching and research institutions in France or abroad, or from public or private research centers.
L'archive ouverte pluridisciplinaire HAL, est destinée au dépôt et à la diffusion de documents scientifiques de niveau recherche, publiés ou non, émanant des établissements d'enseignement et de recherche français ou étrangers, des laboratoires publics ou privés. 
1 Modifications of the soluble proteome of a mediterranean strain of the invasive

\section{2 neurotoxic dinoflagellate Alexandrium catenella under metallic stress conditions}

3

$4 \quad$ Natacha JEAN $^{1(*)}$, Estelle DUMONT ${ }^{1}$, Faouzi HERZI $^{1}$, Thierry BALLIAU ${ }^{2}$, Mohamed 5

6 7 8

$9{ }^{2}$ Plate-forme d'Analyse Protéomique Paris Sud-Ouest (PAPPSO), INRA, Unité Mixte de 10 Recherche en Génétique Végétale (UMR 320), Ferme du Moulon, 91190 Gif-sur-Yvette, 11 France 15

\section{LAABIR $^{3}$, Estelle MASSERET ${ }^{3}$, Stéphane MOUNIER $^{1}$}

\section{France}

${ }^{3}$ MARBEC UMR 9190 IRD-Ifremer-CNRS-Université de Montpellier, Place Eugène

Bataillon, Case 093, 34095 Montpellier Cedex 5, France

E-mail addresses: jean@univ-tln.fr (N. JEAN); estelle.dumont1@gmail.com (E. DUMONT); herzi_faouzi@yahoo.fr $\quad$ F. HERZI); $\underline{\text { balliau@moulon.inra.fr }}$ (T. BALLIAU);

Mohamed.Laabir@umontpellier.fr (M. LAABIR); estelle.masseret@umontpellier.fr (E.

MASSERET); mounier@ univ-tln.fr (S. MOUNIER)

* Corresponding author. Tel.: +33 4941425 29; E-mail address: jean@univ-tln.fr (N. JEAN)
${ }^{1}$ Université de Toulon, PROTEE, EA 3819, 83957 La Garde, France 
Abstract

The soluble proteome of the mediterranean strain ACT03 of the invasive neurotoxic dinoflagellate Alexandrium catenella exposed to lead or zinc at 6,12 or $18 \mathrm{M}$ (total concentrations), or grown under control conditions, has been characterized by twodimensional gel electrophoresis (2-DE). Concentrations of zinc increasingly reduced $(\mathrm{P}<$ $0.05)$ the total number of protein spots constituting the soluble proteome $(-41 \%,-52 \%$ and $60 \%$, at 6,12 or $18 \mathrm{M}$, respectively) of A. catenella ACT03. Besides, most of the proteins constituting the soluble proteome were down-regulated in response to lead or zinc stresses. These proteins were involved mainly in photosynthesis (20-37\% for lead; 36-50\% for zinc) (ribulose-1,5-bisphosphate carboxylase/oxygenase: RUBISCO; ferredoxin-NADP ${ }^{+}$reductase: FNR; peridinin-chlorophyll $a$-protein: PCP) and in the oxidative stress response (29-34\% for lead; $17-36 \%$ for zinc) (superoxide dismutase: SOD; proteasome $\alpha / \beta$ subunits). These harmful effects could be partly compensated by the up-regulation of specific proteins as ATPsynthase $\beta$ subunit (+16.3 fold after exposure to lead at $12 \mathrm{M})$. Indeed, increase in abundance of ATP-synthase could enrich the ATP pool and provide more energy available for the cells to survive under metallic stress conditions, and make more efficient the ATPsynthase transport of metal cations out of the cells. Finally, this study shows that exposure to lead or zinc have a harmful effect on the soluble proteome of A. catenella ACT03, but also suggests a proteomic adaptative response to metallic stresses, which could contribute to sustain this dinoflagellate development in some trace metal-contaminated ecosystems.

Keywords: Alexandrium catenella; harmful algal bloom; proteomics; stress proteins; trace metals; two-dimensional electrophoresis 


\begin{tabular}{llll}
64 & Abbreviations & \\
65 & BiP & Binding immunoglobulin protein \\
66 & CALR & Calreticulin \\
67 & CaM & Calmodulin \\
68 & CHAPS & 3-[3-(cholamidopropyl)-dimethylammonio]1-propanesulfonate \\
69 & 2-DE & Two-dimensional gel electrophoresis \\
70 & DTT & Dithiothreitol \\
71 & DHAP & Dihydroxyacetone phosphate \\
72 & FNR & Ferredoxin-NADP ${ }^{+}$reductase \\
73 & G3P & Glyceraldehyde 3-phosphate \\
74 & HAB & Harmful algal bloom \\
75 & HSP & Heat shock protein \\
76 & IEF & Isoelectric focusing \\
77 & IPG & Immobilized pH gradient \\
78 & LC-MS/MS & Liquid chromatography coupled to tandem mass spectrometry \\
79 & MS & Mass spectrometry \\
80 & MS/MS & Tandem mass spectrometry \\
81 & MW & Molecular weight \\
82 & NCBI & National centre for biotechnology information \\
83 & NADPH & Nicotinamide adenine dinucleotide phosphate \\
84 & PCP & Peridinin-chlorophyll a-protein \\
85 & pI & Isoelectric point \\
86 & PSP & Paralytic shellfish poisoning \\
87 & RBP & Rubisco binding protein \\
88 & ROS & Reactive oxygen species \\
89 & RPI & Ribose-5-phosphate isomerase \\
90 & R5P & Ribose-5-phosphate \\
91 & RUBISCO & Ribulose-1,5-bisphosphate carboxylase/oxygenase \\
92 & RuBP & Ribulose-1,5-bisphosphate \\
93 & Ru5P & Ribose-5-phosphate isomerase \\
94 & SDS & Sodium dodecylsulfate \\
95 & SDS-PAGE & Sodium dodecylsulfate-polyacrylamide gel electrophoresis \\
96 & SOD & Superoxide dismutase \\
97 & & \\
\hline & &
\end{tabular}


Harmful Algal Blooms (HABs) are proliferations of noxious phytoplankton including toxic species, able to (i) threaten human health after the consumption of seafood contaminated by toxins (ii) affect negatively many components of the marine life (shellfish, fishes, seabirds and mammals) (iii) impact socioeconomic activity due to the closure of aquaculture areas during HAB events (Anderson et al., 2012).

Since the last decades, frequency and distribution of HABs have increased in coastal mediterranean ecosytems subject to growing anthropisation (Ferrante et al., 2013). Alexandrium genus, belonging the dinoflagellates, is involved in severe, diverse and widely distributed HABs (Anderson et al., 2012). Indeed, the toxic Alexandrium species (A. catenella, A. fundyense, A. minutum, A. tamarense, A. taylori) can produce saxitoxins and congeners, inducing the Paralytic Shellfish Poisoning (PSP) syndrome.

Occurrences of the Alexandrium genus have been reported in several mediterranean areas receiving trace metal contaminations, as Catalan and Balearic coasts (Bravo et al., 2006; 130 Penna et al., 2005), Tyrrhenian coast (Italy), Thau lagoon (France) (Laabir et al., 2013; Péna and Picot, 1991), Bizerte lagoon (Tunisia) (Fertouna et al., 2015) and Toulon Bay (western Mediterranean, France) (Abadie, personal communication; Jean et al., 2005, 2006). This latter is a severely trace metal contaminated ecosystem, both in the water column and the sediments (Jean et al., 2012; Tessier et al., 2011). Thus, occurrence of Alexandrium in such area, suggests that it could be potentially tolerant to trace metal contaminations, although this has not been demonstrated so far. Consequently, studies should be carried out to characterize the potential tolerance of Alexandrium to metallic stresses, which could contribute to explain its development in metal polluted anthropized environments.

In response to changes in the environment, an organism can modify its proteome by increasing or decreasing the expression of some proteins, making proteomics a dynamic field of investigation. These modifications, activating or slowing down some metabolic pathways, allow the organism to adapt to environmental changes. Therefore, modifications of the proteome are at the basis of the adaptive organism response to environmental stresses, as suggested in studies reporting higher protein expression (for actin and calreticulin) in zooplankton communities sampled in the most metal polluted stations of Toulon Bay (Jean et al., 2012).

Many studies have characterized the proteomic responses of aquatic organisms exposed to metal stresses, whether these are marine pluricellulars, as Chlamys farreri 
149 (scallop) (Gao et al., 2007), Eriocheir sinensis (crab) (Silvestre et al., 2006), Montastraea

franksi (coral) (Venn et al., 2009), Mytilus edulis (mussel) (Sanders and Martin, 1991), Perna veridis (bivalve) (Leung et al., 2011), Saccostrea glomerata and Crassostrea gigas (oyster) (Choi et al., 2008; Thompson et al., 2011, 2012), Ectocarpus siliculosus, Fucus serratus, Lessonia nigrescens, Sargassum fusiforme and Scytosiphon gracilis (brown algae) (Contreras et al., 2010; Ireland et al., 2004, Lovazzano et al., 2013; Ritter et al., 2010; Zou et al., 2015), or aquatic unicellulars, as Anabaena sp. (Pandey et al., 2012), Klebsiella pneumoniae, Pseudomonas aeruginosa and Pseudomonas fluorescens (Daware et al., 2012; Kiliç et al., 2010; Poirier et al., 2008) or Tetrahymena pyriformis (Zhang et al., 2012). However, only one study has been devoted to the characterization of the proteomic response of a dinoflagellate, Karenia brevis, notably submitted to lead contamination, and in which some proteins (heat shock $60 \mathrm{kDa}$ protein and superoxide dismutases) have been induced by the metal stress (Miller-Morey and Van Dolah, 2004).

Under an ecotoxicoproteomic approach, the purpose of the present study is to characterize the proteomic response to metallic stresses, of the invasive neurotoxic dinoflagellate Alexandrium catenella. A monoclonal mediterranean strain of A. catenella exposed to metallic contaminations, either by lead (toxic for the cells whatever its concentration), or by zinc (first required by the cells as a trace element, then harmful at higher concentrations), has been used. Then, the soluble proteomes of this strain, grown respectively under control and metallic stress conditions, have been characterized by two-dimensional gel electrophoresis (2-DE), and compared. This comparison has generated a list of proteins of interest whose expression was significantly modified in response to the metallic stresses. The proteins of interest can be considered as potential biomarkers of metallic stresses in the A. catenella cells. Besides, they provide informations about the metabolic pathways which were modified in A. catenella under metallic stress conditions. Some of these proteins could be candidates as potential detoxification and protection processes in A. catenella, thus contributing to its adaptive response and tolerance capacity towards metallic stresses. Consequently, the overall results obtained could allow to understand the biochemichal mechanisms making A. catenella able to develop in anthropized coastal marine ecosystems contaminated by trace metals. 


\section{Materials and Methods}

\subsection{Cultures of Alexandrium catenella ACT03}

A. catenella strain ACT03 was obtained after isolation of a single vegetative cell from seawater sample collected during a toxic bloom event in October 2003, in Thau lagoon (Laabir et al., 2013). It was maintained in enriched $\mathrm{f} / 2$ culture medium (Guillard and Ryther, 1962), at $20^{\circ} \mathrm{C}$ in sterile $250 \mathrm{~mL}$ flasks $\left(75 \mathrm{~cm}^{2}\right.$ Greiner, Dominique Dutscher SAS), with a 12h: $12 \mathrm{~h}$ photoperiod and under a light intensity of 135 mol photons $\mathrm{m}^{-2} \mathrm{~s}^{-1}$ (Herzi et al., 2013, 2014). Natural seawater filtered through a GF/F glass fibre filter $(\varnothing=47 \mathrm{~mm}$, Whatman) and then sterilized was used as a basis for the culture medium.

To study modifications of the soluble proteome of A. catenella ACT03 under metallic stress, the culture medium was supplemented with sterile stock solutions of trace metals prepared with $\mathrm{ZnSO}_{4}, 7 \mathrm{H}_{2} \mathrm{O}$, or with $\mathrm{Pb}\left(\mathrm{CH}_{3} \mathrm{COO}\right)_{2}, 3 \mathrm{H}_{2} \mathrm{O}$ salts dissolved in ultrapure water. For each metal, three total concentrations $(6,12$ and $18 \mathrm{M})$ were tested. A metal-free culture medium was considered as the control. Based on the MINEQLprogram and on the known composition of the $f / 2$ culture medium, the corresponding free metal concentrations $\left(\mathrm{Zn}^{2+}\right.$ or $\left.\mathrm{Pb}^{2+}\right)$ bioavailable for toxicity towards cells, were calculated (Table I) (Herzi et al., 2014).

Table I. Total $\left(\mathrm{M}^{2+} \mathrm{T}\right)$ and free $\left(\mathrm{M}^{2+}{ }_{\mathrm{F}}\right)$ trace metal concentrations (expressed in $\left.\mathrm{M}\right)$, used for lead and zinc contaminations of the Alexandrium catenella ACT03 cultures

\begin{tabular}{ccc}
\hline$\left[\mathbf{M}^{2+}\right]_{\mathbf{T}}(\mathbf{M})$ & {$\left[\mathbf{P b}^{2+}\right]_{\mathbf{F}}(\mathbf{M})$} & {$\left[\mathbf{Z n}^{2+}\right]_{\mathbf{F}}(\mathbf{M})$} \\
\hline $6 \times 10^{-6}$ & $1.1 \times 10^{-8}$ & $2.8 \times 10^{-7}$ \\
$12 \times 10^{-6}$ & $2.6 \times 10^{-8}$ & $6.2 \times 10^{-7}$ \\
$18 \times 10^{-6}$ & $4.4 \times 10^{-8}$ & $1.0 \times 10^{-6}$ \\
\hline
\end{tabular}

\subsection{Preparation of the protein extracts}

Control and metal-contaminated cultures were studied at the end of their exponential phase-early stationary phase of growth. Cell density of these cultures was estimated by counting (in triplicates) all the cells in $50 \mathrm{~L}$ sub-sample of a $1 \mathrm{~mL}$ Lugol fixed culture, with an inverted microscope (magnification: $100 \times$ ). Taking the obtained density into account, a volume of culture containing $8 \times 10^{6}$ cells was used for proteomic analysis.

The sample was centrifuged for $15 \mathrm{~min}$ at $1500 \mathrm{~g}$, at $15^{\circ} \mathrm{C}$. The obtained cell pellet was washed twice in natural seawater (prepared as described in 2.1.), for $10 \mathrm{~min}$ at $15000 \mathrm{~g}$, to be immediately used. As recommended in Wang et al. (2008), the washed pellet was then re-suspended in an extraction solution, containing $2 \mathrm{~mL} 40 \mathrm{mM}$ Tris at $\mathrm{pH} 8.7,2.4 \mathrm{~L}$ 
215 benzonase nuclease (Sigma-Aldrich) and $10 \mathrm{~L}$ of protease inhibitor cocktail (SigmaAldrich). Then, protein extraction was achieved by sonication of the obtained suspension in an ice-water bath, using a microtip Vibra Cell 73424 (Bioblock Scientific) during 3 min at 50 $\mathrm{W}$ and $25 \mathrm{kHz}$, with $10 \mathrm{~s}$ on/ $10 \mathrm{~s}$ off cycles. Then, the solution was centrifuged for $30 \mathrm{~min}$ at $15000 \mathrm{~g}$, to obtain a supernatant which contains the soluble protein extract. This fraction was further concentrated by ultrafiltration at $1500 \mathrm{~g}$, at $15^{\circ} \mathrm{C}$, through Vivaspin concentrator tubes with molecular weight cutoff membranes of $15 \mathrm{kDa}$ (15R Hydrosart $10 \mathrm{kDa}$, Thermo Fisher Scientific), until reaching a volume of 150 L. To obtain the protein extract ready to be used for proteomics, the concentrate had to be finally mixed with $400 \mathrm{~L}$ of a sample solution consisting of urea (7 M), thiourea (2 M), CHAPS (1\% w/v), Triton X-100 (3\% v/v), DTT $(1 \% \mathrm{w} / \mathrm{v})$, carrier ampholytes $(0.2 \% \mathrm{v} / \mathrm{v})$ and bromophenol blue $(0.002 \% \mathrm{v} / \mathrm{v})$.

\subsection{Protein determination}

Protein determination of the extracts was achieved according to Lowry et al. (1951), using the Reagent Compatible Detergent Compatible Protein Assay (RC DC Protein Assay, Bio-Rad), and bovine serum albumin (BSA) as standard.

\subsection{Two-dimensional electrophoresis}

A pre-prepared immobilized pH gradient (IPG) strip (17 cm length, linear gradient, pH 3-10, Bio-Rad) was used, on which the extract sample (350 L containing 200 g proteins) was transferred (Linares et al., 2016). The rehydration of the IPG strip in presence of the sample, and then isoelectric focusing (IEF), were performed in the horizontal electrophoresis system PROTEAN IEF Cell (Bio-Rad), at $20^{\circ} \mathrm{C}$, in the following manner: 18 $\mathrm{h}$ at $50 \mathrm{~V}$ (active rehydration), $2 \mathrm{~h}$ at $100 \mathrm{~V}, 2 \mathrm{~h}$ at $250 \mathrm{~V}, 2 \mathrm{~h}$ at $500 \mathrm{~V}, 2 \mathrm{~h}$ at $1000 \mathrm{~V}, 2 \mathrm{~h}$ at $4000 \mathrm{~V}$ and $5 \mathrm{~h}$ at $10000 \mathrm{~V}$, so as to reach a total minimal value of $60000 \mathrm{Vh}$ for each loaded IPG strip. After IEF, the IPG strip was successively equilibrated for $10 \mathrm{~min}$ at room temperature in equilibration buffers 1 (6 M urea, 2\% w/v SDS, $0.375 \mathrm{M}$ Tris $\mathrm{pH} 8.8,20 \% \mathrm{v} / \mathrm{v}$ glycerol, 2\% w/v DTT) and 2 (6 M urea, 2\% w/v SDS, $0.375 \mathrm{M}$ Tris $\mathrm{pH} 8.8,20 \% \mathrm{v} / \mathrm{v}$ glycerol, $2.5 \% \mathrm{w} / \mathrm{v}$ iodoacetamide).

Sodium dodecylsulfate polyacrylamide gel electrophoresis (SDS-PAGE) was performed according to Laemmli (1970). The equilibrated IPG strip was placed in dyed (BPB) melted agarose, across a handmade polyacrylamide gel $(18 \mathrm{~cm} \times 18 \mathrm{~cm} \times 1 \mathrm{~mm}$; stacking gel: 5\%, resolving gel: 11\%). A volume of $20 \mathrm{~L}$ of molecular weight marker solution (10-250 kDa range, Precision Plus Protein Standards Dual Color, Bio-Rad) was 
249 loaded at the left top of the gel. The gels were run at $4^{\circ} \mathrm{C}$ in a Protean II XL (Bio-Rad), with a constant current of $20 \mathrm{~mA}$ per gel for $1 \mathrm{~h}$, and then, with a constant current of $30 \mathrm{~mA}$ per gel until the dye reached the bottom of the gel. After SDS-PAGE, gels were washed three times for $5 \mathrm{~min}$ in ultrapure water, then stained with the Imperial Protein Stain (Thermo Fisher Scientific) under orbital shaking for $1 \mathrm{~h} 30 \mathrm{~min}$, to be destained in ultrapure water until visualization of separated protein spots. Each gel presented (Figures $1 \& 2$ ) is representative of three different biological gel replicates. The protein spots on the gels were analysed using the PD Quest 2-D Analysis Software 8.0.1 version (Bio-Rad). Abundance of a given protein spot has been obtained after normalization, as the ratio (in \%) of its individual abundance on the abundance of all the marker bands.

\subsection{Tracking of protein of interest in the soluble proteome of $A$. catenella ACT03}

Among the proteins making the soluble proteome of A. catenella ACT03, the proteins of interest are those whose expression was significantly affected by the metallic stresses, through up- or down-regulation, or through appearance or disappearance. The up- or downregulated proteins were respectively tracked thanks to the ratio of the abundance of each protein spot on the $2 \mathrm{D}$-gel after metallic stress, on the abundance on the $2 \mathrm{D}$-gel under control conditions (for up-regulation), and the ratio of the abundance of each protein spot on the 2Dgel under control conditions, on the abundance on the 2D-gel after metallic stress (for downregulation). First, to be considered as a protein of interest, a protein had a ratio greater than or equal to 2 (Bae et al., 2003). Then, a statistical Student test was applied between the abundances of this protein on the 2D-gel replicates obtained under metallic stress conditions, and the abundances of this same protein on the 2D-gel replicates under control condition. This statistical test allowed to determine if the fold difference in up-regulation or down-regulation was significant (very significant: $\mathrm{P}<0.01$; significant: $0.01<\mathrm{P}<0.05$; rather significant: $0.05<\mathrm{P}<0.10$ ), in which case, the concerned protein was significantly up-regulated or down-regulated, and considered as a protein of interest. The other proteins of interest were those appearing or disappearing on at least two 2D-gels among the three obtained replicates. 


\subsection{Protein identification by liquid chromatography tandem mass spectrometry}

Proteins of interest were picked on gel in order to be identified by mass spectrometry. In-gel digestion of the picked 2-D spots was performed with the Progest system (Genomic Solution) according to a standard trypsin protocol (Page et al., 2010). HPLC was performed on a NanoLC-Ultra system (Eksigent). A 4 L sample of the peptide solution was loaded at $7.5 \mathrm{~L} \mathrm{~min}^{-1}$ on a precolumn cartridge (stationary phase: $\mathrm{C} 18$ Biosphere, $5 \mathrm{~m}$; column: 100 $\mathrm{m}$ inner diameter, $2 \mathrm{~cm}$; Nanoseparations) and desalted with $0.1 \% \mathrm{HCOOH}$. After $3 \mathrm{~min}$, the precolumn cartridge was connected to the separating PepMap C18 column (stationary phase: C18 Biosphere, 3 m; column: 75 m inner diameter, 150 mm; Nanoseparations). Buffers A and $\mathrm{B}$ respectively were prepared with $0.1 \% \mathrm{HCOOH}$ in water, and with $0.1 \% \mathrm{HCOOH}$ in acetonitrile. The peptide separation was achieved with a linear gradient from 5 to $30 \%$ B for $28 \mathrm{~min}$ at $0.3 \mathrm{~L} \mathrm{~min}^{-1}$. Including the regeneration step at $95 \% \mathrm{~B}$ and the equilibration step at $95 \% \mathrm{~A}$, one run took $45 \mathrm{~min}$.

Eluted peptides were on-line analyzed with an LTQ XL ion trap (Thermo Electron) using a nanoelectrospray interface. Ionization $(1.5 \mathrm{kV}$ ionization potential) was performed with liquid junction and a non-coated capillary probe (10 $\mathrm{m}$ inner diameter; New Objective). Peptide ions were analysed using Xcalibur 2.07 with the following data-dependent acquisition steps: (1) full MS scan (mass to-charge ratio $(\mathrm{m} / \mathrm{z}$ ) 300-1 400, centroid mode) and (2) MS/MS $(\mathrm{qz}=0.25$, activation time $=30 \mathrm{~ms}$, and collision energy $=35 \%$; centroid mode). Step 2 was repeated for the three major ions detected in step 1. Dynamic exclusion was set to $30 \mathrm{~s}$.

A database search was performed with XTandem (version 2010.12.01.1) (http://www.thegpm.org/TANDEM/). Enzymatic cleavage was declared as a trypsin digestion with one possible miscleavage. Cys carboxyamidomethylation and Met oxidation were set to static and possible modifications, respectively. Precursor mass and fragment mass tolerance were 2.0 and 0.8 , respectively. A refinement search was added with similar parameters except that semi-trypsic peptide, and possible N-ter proteins acetylation were searched. The UniprotKB database (http://www.uniprot.org/) restricted to Metazoa excepted Mammalia (1755330 entries, version 201201), and a contaminant database (trypsin, keratins.) were used. Only peptides with an $E$ value smaller than 0.1 were reported.

Identified proteins were filtered and grouped using XTandem Pipeline (http://pappso.inra.fr/bioinfo/xtandempipeline/) according to: (1) A minimum of two different peptides required with an $E$ value smaller than 0.05 , (2) a protein $E$ value (calculated as the product of unique peptide $E$ values) smaller than $10^{-4}$. In the case of identification with only two or three MS/MS spectra, similarity between the experimental and the theoretical MS/MS 
317 spectra was visually checked. Identification by database searching was completed by a de novo approach. Peptides sequences were determined by automatic de novo interpretation from MS/MS spectra, using PepNovo software (version 2010225). This analysis was performed on MS/MS spectra with a quality score smaller than 0.1. Trypsin digestion, Cys carboxyamidomethylation and Met oxidation were set to enzymatic cleavage, static and possible modifications, respectively. Only sequences with a score greater than 70 were selected.

Homology searches were performed by Fasts software (version 36.06) using the MD20-MS matrix. Sequences corresponding to keratins or trypsin were firstly removed by interrogating a homemade contaminant database. Secondly, the search computing process was carried out on the same database. Homologies with a minimum of two independent peptides and an $E$ value smaller than 0.001 , were only selected. In all cases, the automatic de novo interpretation of MS/MS spectra was visually confirmed. Since the genome of A. catenella has not been fully sequenced, protein identification has been performed by homology with the known peptidic sequences from the National Centre for Biotechnology Information (NCBI) protein database (http://www.ncbi.nlm.nih.gov/), preferentially coming from, in this order: (i) other Alexandrium species (A. fundyense, A.minutum, A. ostenfeldii) (ii) other dinoflagellates (Amphidinium carterae, Gonyaulax polyedra, Heterocapsa triquetra, Karlodinium micrum, Oxyrrhis marina) (iii) other microalgae (Crypthecodinium cohnii, Symbiodinium sp.) (iv) Protozoans (Neospora caninum, Paramecium tetraurelia, Plasmodinium berghei, Tetrahymena thermophila, Toxoplasma gondii). 
3. Results 352 353 354 855

The results of mass spectrometry protein identification are shown in Table II (see also SuppData 1).

Table II. LC-MS/MS identification of the proteins up- or down-regulated in the soluble proteome of Alexandrium catenella ACT03 under metallic stresses (lead or zinc at 6,12 or $18 \mathrm{M}$ )

\begin{tabular}{|c|c|c|c|c|c|c|}
\hline \multirow{2}{*}{ Spot } & \multirow{2}{*}{$\begin{array}{l}\text { Peptide } \\
\text { number }\end{array}$} & \multicolumn{2}{|c|}{$\mathrm{MW}(\mathrm{kDa}) / \mathrm{pI}$} & \multirow{2}{*}{ Protein name } & \multirow{2}{*}{$\begin{array}{l}\text { Species } \\
\text { Accession number }\end{array}$} & \multirow{2}{*}{ Putative function } \\
\hline & & $\operatorname{Exp}$ & Theo & & & \\
\hline 28 & 13 & $19.8 / 5.6$ & $33.2 / 5.9$ & Ribose-5-phosphate isomerase & $\begin{array}{l}\text { Heterocapsa triquetra } \\
\text { Q5ENN9 }\end{array}$ & $\begin{array}{l}\text { Pentose phosphate pathway } \\
(02.07)\end{array}$ \\
\hline 9 & 25 & $38.8 / 5.9$ & $59.5 / 5.4$ & $\begin{array}{l}\text { Ribulose-1,5-bisphosphate } \\
\text { carboxylase }\end{array}$ & $\begin{array}{l}\text { Gonyaulax polyedra } \\
\text { Q42813 }\end{array}$ & Photosynthesis (02.30) \\
\hline 29 & 16 & $21.6 / 5.7$ & $79.1 / 5.8$ & $\begin{array}{l}\text { Ribulose-1,5-bisphosphate } \\
\text { carboxylase }\end{array}$ & $\begin{array}{l}\text { Heterocapsa triquetra } \\
\text { Q5ENN5 }\end{array}$ & Photosynthesis (02.30) \\
\hline 4 & 15 & $25.0 / 5.9$ & $20.6 / 8.8$ & $\begin{array}{l}\text { Peridinin-chlorophyll } a \text { - } \\
\text { binding protein }\end{array}$ & $\begin{array}{l}\text { Heterocapsa pygmaea } \\
\text { Q9FEY3 }\end{array}$ & Light absorption (02.45.03) \\
\hline 34 & 17 & $25.7 / 6.9$ & $37.8 / 6.6$ & $\begin{array}{l}\text { Peridinin-chlorophyll } a \text { - } \\
\text { binding protein }\end{array}$ & $\begin{array}{l}\text { Symbiodinium sp. } \\
\text { P51874 }\end{array}$ & Light absorption (02.45.03) \\
\hline 36 & 3 & $24.8 / 6.4$ & $38.0 / 9.1$ & $\begin{array}{l}\text { Peridinin-chlorophyll } a \text { - } \\
\text { binding protein }\end{array}$ & $\begin{array}{l}\text { Symbiodinium sp. } \\
\text { AFH } 88375\end{array}$ & Light absorption (02.45.03) \\
\hline 41 & 18 & $24.6 / 6.7$ & $38.9 / 9.0$ & $\begin{array}{l}\text { Peridinin-chlorophyll } a \text { - } \\
\text { binding protein }\end{array}$ & $\begin{array}{l}\text { Gonyaulax polyedra } \\
\text { O00941 }\end{array}$ & Light absorption (02.45.03) \\
\hline 43 & 17 & $25.7 / 6.7$ & $38.2 / 8.7$ & $\begin{array}{l}\text { Peridinin-chlorophyll } a \text { - } \\
\text { binding protein }\end{array}$ & $\begin{array}{l}\text { Amphidinium carterae } \\
\text { P80484 }\end{array}$ & Light absorption (02.45.03) \\
\hline 44 & 20 & $25.8 / 6.5$ & $37.8 / 6.6$ & $\begin{array}{l}\text { Peridinin-chlorophyll } a \text { - } \\
\text { binding protein }\end{array}$ & $\begin{array}{l}\text { Symbiodinium sp } \\
\text { P51874 }\end{array}$ & Light absorption (02.45.03) \\
\hline 46 & 7 & $25.8 / 6.2$ & $38.0 / 9.1$ & $\begin{array}{l}\text { Peridinin-chlorophyll } a \text { - } \\
\text { binding protein }\end{array}$ & $\begin{array}{l}\text { Symbiodinium sp. } \\
\text { AFH } 88375\end{array}$ & Light absorption (02.45.03) \\
\hline 16 & 3 & $49.4 / 5.1$ & $60.0 / 6.4$ & ATP beta synthase subunit & $\begin{array}{l}\text { Neospora caninum } \\
\text { F0VGD5 }\end{array}$ & Energy generation $(02.45 .15)$ \\
\hline 6 & 11 & $24.3 / 5.3$ & $74.3 / 5.1$ & $\mathrm{BiP}$ & $\begin{array}{l}\text { Crypthecodinium cohnii } \\
\text { Q8S4R0 }\end{array}$ & Chaperone (14.01) \\
\hline 47 & 5 & $25.0 / 6.2$ & $74.3 / 5.1$ & $\mathrm{BiP}$ & $\begin{array}{l}\text { Crypthecodinium cohnii } \\
\text { Q8S4R0 }\end{array}$ & Chaperone (14.01) \\
\hline 10 & 2 & $18.9 / 5.4$ & $70.6 / 5.1$ & HSP70 & $\begin{array}{l}\text { Crypthecodinium cohnii } \\
\text { Q8S4Q8 }\end{array}$ & Chaperone (14.01) \\
\hline 40 & 7 & $22.9 / 5.3$ & $70.6 / 5.1$ & HSP70 & $\begin{array}{l}\text { Crypthecodinium cohnii } \\
\text { Q8S4Q8 }\end{array}$ & Chaperone (14.01) \\
\hline 5 & 2 & $24.5 / 5.8$ & $29.0 / 5.4$ & Proteasome alpha subunit & $\begin{array}{l}\text { Perkinsus marinus } \\
\text { XP_002775560 }\end{array}$ & $\begin{array}{l}\text { Proteasomal degradation } \\
(14.13 .01 .01)\end{array}$ \\
\hline 30 & 4 & $20.4 / 6.0$ & $22.6 / 6.1$ & Proteasome beta subunit & $\begin{array}{l}\text { Daphnia magna } \\
\text { JAN48661 }\end{array}$ & $\begin{array}{l}\text { Proteasomal degradation } \\
(14.13 .01 .01)\end{array}$ \\
\hline 33 & 3 & $15.6 / 5.8$ & $27.9 / 5.8$ & Proteasome alpha subunit & $\begin{array}{l}\text { Perkinsus marinus } \\
\text { XP_002764909 }\end{array}$ & $\begin{array}{l}\text { Proteasomal degradation } \\
(14.13 .01 .01)\end{array}$ \\
\hline 35 & 4 & $24.8 / 6.5$ & $27.9 / 5.8$ & Proteasome alpha subunit & $\begin{array}{l}\text { Perkinsus marinus } \\
\text { XP_002764909 }\end{array}$ & $\begin{array}{l}\text { Proteasomal degradation } \\
(14.13 .01 .01)\end{array}$ \\
\hline 37 & 7 & $23.8 / 6.6$ & $27.9 / 5.8$ & Proteasome alpha subunit & $\begin{array}{l}\text { Perkinsus marinus } \\
\text { XP_002764909 }\end{array}$ & $\begin{array}{l}\text { Proteasomal degradation } \\
(14.13 .01 .01)\end{array}$ \\
\hline 45 & 8 & $25.8 / 6.4$ & $27.9 / 5.8$ & Proteasome alpha subunit & $\begin{array}{l}\text { Alexandrium fundyense } \\
\text { A4UHA5 }\end{array}$ & $\begin{array}{l}\text { Proteasomal degradation } \\
(14.13 .01 .01)\end{array}$ \\
\hline 19 & 10 & $18.1 / 6.2$ & $27.2 / 5.0$ & Calreticulin & $\begin{array}{l}\text { Heterocapsa triquetra } \\
\text { Q5ENL5 }\end{array}$ & Calcium binding (16.17.01) \\
\hline 26 & 3 & $14.1 / 4.5$ & $16.8 / 4.1$ & Calmodulin & $\begin{array}{l}\text { Prorocentrum minimum } \\
\text { AAL61535 }\end{array}$ & Calcium binding (16.17.01) \\
\hline 7 & 17 & $31.7 / 6.4$ & $45.0 / 7.0$ & Ferredoxin-NADP ${ }^{+}$- reductase & $\begin{array}{l}\text { Crypthecodinium cohnii } \\
\text { Q5ENS9 }\end{array}$ & Electron transport (20.01.15) \\
\hline 8 & 19 & $31.7 / 6.3$ & $45.0 / 7.0$ & Ferredoxin-NADP ${ }^{+}$- reductase & $\begin{array}{l}\text { Heterocapsa triquetra } \\
\text { Q5ENS9 }\end{array}$ & Electron transport (20.01.15) \\
\hline 21 & 23 & $32.8 / 5.9$ & $45.0 / 7.0$ & Ferredoxin-NADP ${ }^{+}$- reductase & $\begin{array}{l}\text { Heterocapsa triquetra } \\
\text { Q5ENS9 }\end{array}$ & Electron transport (20.01.15) \\
\hline 39 & 2 & $34.1 / 5.7$ & $45.0 / 7.0$ & Ferredoxin-NADP ${ }^{+}$- reductase & $\begin{array}{l}\text { Heterocapsa triquetra } \\
\text { Q5ENS9 }\end{array}$ & Electron transport (20.01.15) \\
\hline 25 & 11 & $18.2 / 5.3$ & $17.9 / 5.9$ & Superoxide dismutase $[\mathrm{Cu}-\mathrm{Zn}]$ & $\begin{array}{l}\text { Tetrahymena thermophila } \\
\text { Q22H00 }\end{array}$ & Detoxification (32.07) \\
\hline 1 & 22 & $29.2 / 4.8$ & & $\begin{array}{l}\text { Chromosome undetermined } \\
\text { scaffold_2 }\end{array}$ & $\begin{array}{l}\text { Paramecium tetraurelia } \\
\text { A0CJD5 }\end{array}$ & Unclassified protein (99) \\
\hline 12 & 16 & $31.7 / 4.3$ & $50.3 / 5.1$ & Hypothetical protein & $\begin{array}{l}\text { Plasmodium berghei } \\
\text { Q4YAV6 }\end{array}$ & Unclassified protein (99) \\
\hline 31 & 3 & $19.4 / 4.8$ & & Unknown & $\begin{array}{l}\text { Alexandrium minutum } \\
\text { GW796469 }\end{array}$ & Unclassified protein (99) \\
\hline 32 & 2 & $14.1 / 5.4$ & & Unknown & $\begin{array}{l}\text { Oxyrrhis marina } \\
\text { EG736358 }\end{array}$ & Unclassified protein (99) \\
\hline
\end{tabular}




\subsection{Modifications of the soluble proteome under lead exposure}

Whatever its concentration, lead did not induce a significant $(\mathrm{P}>0.05)$ decrease in the total number of protein spots constituting the soluble proteome of A. catenella ACT03 (6 M: $240 \pm 74$ spots; 12 M: $202 \pm 98$ spots; 18 M: $239 \pm 92$ spots), compared to the control (339 \pm 89 spots) (Figures $1 \mathrm{~A} \& 1 \mathrm{~B})$.

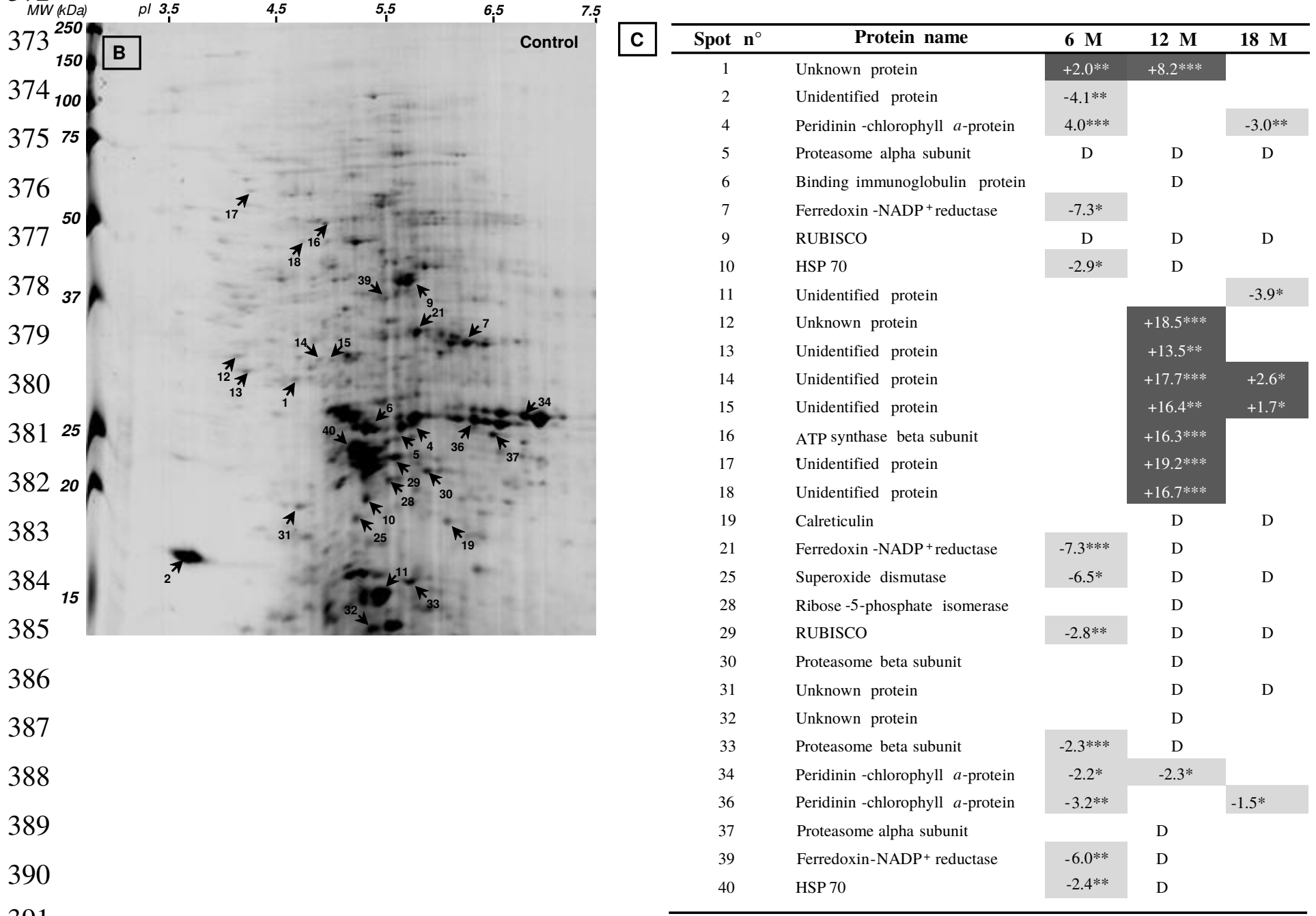


Figure 1. Representative 2-DE maps comparing the soluble proteomes of Alexandrium catenella ACT03 grown under exposure to lead 6,12 or $18 \mathrm{M}\left(\left[\mathrm{Pb}^{2+}\right]_{\mathrm{F}}=11,26\right.$ and $44 \mathrm{nM}$ respectively) and control conditions. $(\mathbf{A})$ : Protein profiles of Alexandrium catenella ACT03 grown under exposure to lead 6, 12 or 18 M (B): Protein profile of Alexandrium catenella ACT03 grown under control condition. Proteins of interest are identified by their spot numbers $(\mathbf{C})$ : Names of the proteins of interest are shown with the fold differences in their expression, according to the level of lead exposure. In black, up-regulated proteins; in grey, down-regulated proteins; D, disappeared proteins. ${ }^{*},{ }^{* *}$ and ${ }^{* * * *}$ : proteins whose expression was different under lead exposure, with $0.05<\mathrm{P}<$ $0.10 ; 0.01<\mathrm{P}<0.05$ and $\mathrm{P}<0.01$, respectively

\section{1.a. Exposure to lead $6 \mathrm{M}$}

Exposure to lead $6 \mathrm{M}$ led to 46 proteins of interest (i.e. whose expression was significantly modified in comparison with control: $\mathrm{P}<0.10)$ (Figures $1 \mathrm{~B} \& \mathrm{1C}$ ). Among these differentially expressed proteins, 12 proteins could be identified, which were significantly down-regulated, whereas only one protein, not recognized in the protein database, was significantly up-regulated. The down-regulated proteins are: $(i)$ involved in photosynthesis, for RUBISCO (spots 9 and 29), PCP (spots 4, 34 and 36) and FNR (spots 7, 21 and 39) (ii) involved in the response to oxidative stress, as proteasome $\alpha$ subunit (spots 5 and 33) and SOD (spot 25) (iii) the chaperone HSP 70 (spots 10 and 40). The fold differences in expression of these proteins ranged from -7.3 to +2.0 fold, with the highest harmful effect on FNR (-7.3 fold) (spots 7 and 21) (Figure 1C).

\section{1.b. Exposure to lead $12 M$}

Exposure to lead $12 \mathrm{M}$ led to 82 proteins of interest $(\mathrm{P}<0.10)$. Eight proteins were significantly up-regulated and 17 proteins were significantly down-regulated (Figures 1B \& 1C). Only one protein up-regulated could be identified: it was the ATP-synthase $\beta$ subunit (spot 16), involved in energy metabolism. Fold differences in expression of the up-regulated proteins reached the highest values observed in this study, i.e. exceeding +16.0 fold (for spots 12 and 15-18) (Figure 1C). These results showed the strong effect of lead $12 \mathrm{M}$ on this protein up-regulation. This effect was opposite regarding the down-regulated proteins: $(i)$ PCP (spot 34), RUBISCO (spots 9 and 29) and FNR (spots 21 and 39) involved in photosynthesis (ii) proteasome $\alpha / \beta$ subunits (spots 5, 30, 33 and 37) and SOD (spot 25) implied in the response to oxidative stress (iii) CALR (spot 19) chaperone also involved in $\mathrm{Ca}^{2+}$ binding (iv) RPI (spot 28) taking part in carbohydrate metabolism (v) HSP 70 (spots 10 and 40) and BiP (spot 6), two chaperones. 


\section{1.c. Exposure to lead $18 \mathrm{M}$}

A number of 59 proteins of interest $(\mathrm{P}<0.10)$ have been detected in response to exposure to lead 18 M (Figures 1B \& 1C). These proteins of interest were mainly downregulated. Among them, we have identified: (i) RUBISCO (spots 9 and 29), enzyme at the root of photosynthesis (ii) proteasome $\alpha$ subunit (spot 5) and SOD (spot 25), involved in the response to oxidative stress (iii) CALR (spot 19), chaperone also involved in $\mathrm{Ca}^{2+}$ binding (iv) PCP (spots 4 and 36), implied in photosynthetic activity. Finally, two proteins have been significantly up-regulated (spots 14 and 15), with a moderate fold difference around +2.0 fold, but their identification has not been successful (Figure 1C).

\section{1.d. Intercomparison of the proteomic modifications under lead stresses}

No significant $(\mathrm{P}>0.05)$ difference was observed between the total numbers of proteins constituting the soluble proteomes of A. catenella respectively exposed to lead 6, 12 or 18 M (Figure 1A). However, in comparison with the other concentrations, lead at $12 \mathrm{M}$ induced the greatest number of modifications in protein expression ( 82 proteins of interest), with the highest numbers of up-regulated and down-regulated proteins (Figures 1B \& 1C). Besides, lead at $12 \mathrm{M}$ induced the maximal fold differences in up-regulation, reaching between +13.5 (spot 13) and +19.2 (spot 17) fold (Figures 1B \& 1C).

Whatever the lead concentration, the proteins RUBISCO (spot 9) and proteasome $\alpha$ subunit (spot 5) disappeared (Figures 1B \& 1C, Figure 1S in SuppData 2). On the other hand, SOD (spot 25) ended up disappearing after exposure to lead at $12 \mathrm{M}$ and $18 \mathrm{M}$. Such a harmful effect was also observed for HSP 70 (spots 10 and 40), FNR (spots 21 and 39), RUBISCO (spot 29) and proteasome $\alpha$ subunit (spot 33). In contrast, only ATP-synthase $\beta$ subunit (spot 16) was up-regulated after exposure to lead at $12 \mathrm{M}$. 


\section{3.2. Modifications of the soluble proteome under zinc exposure}

1

In comparison with control $(339 \pm 89$ spots $)$, systematical significant $(\mathrm{P}<0.05)$

466 decreases in the total numbers of protein spots were observed in the soluble proteomes of $A$.

467 catenella ACT03 exposed to: zinc 6 M: $200 \pm 11$ spots (-41\%); zinc 12 M: $162 \pm 90$ spots

468 (-52\%); zinc 18 M: $136 \pm 37$ spots (-60\%) (Figures 2A \& 2B).
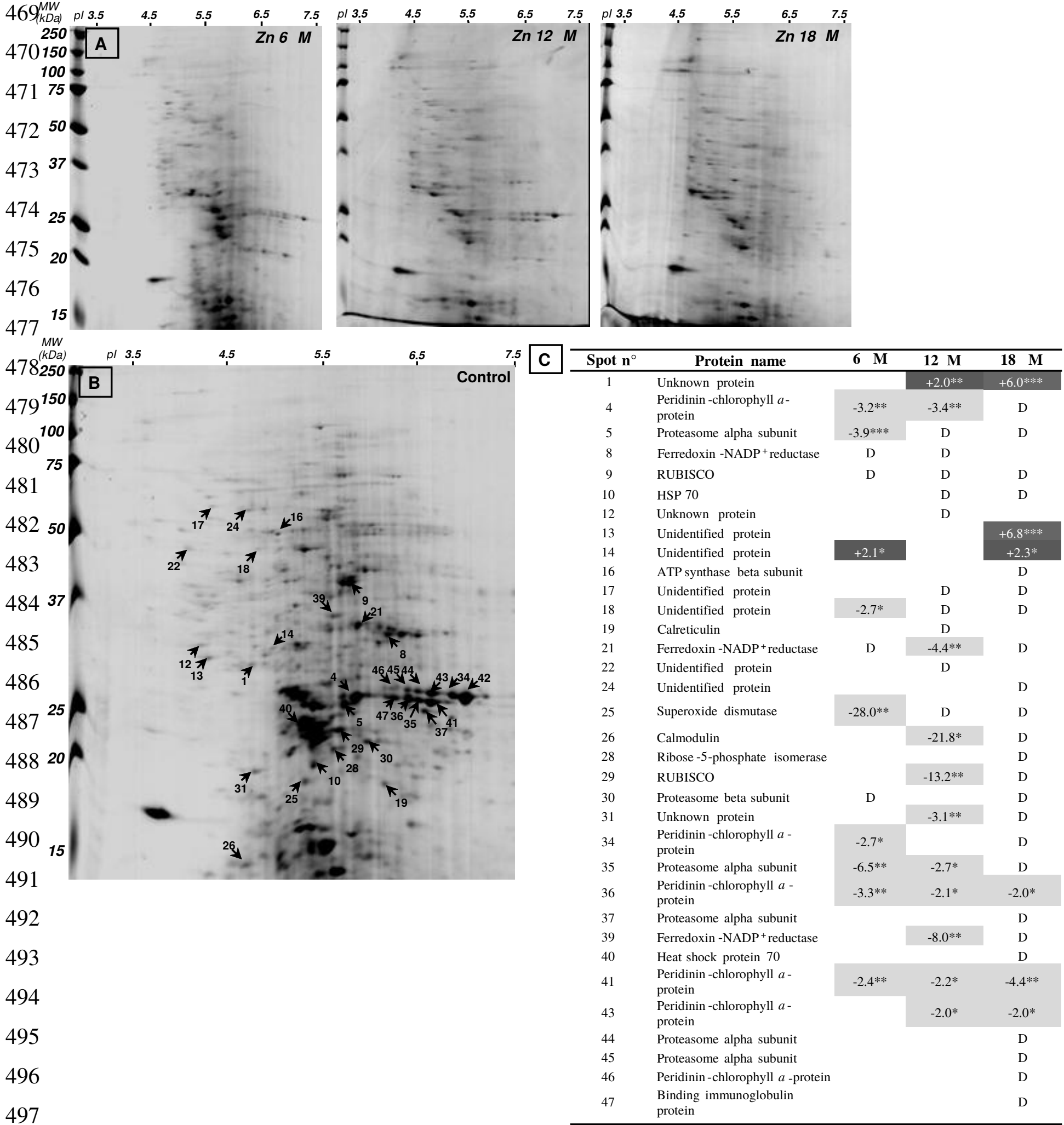
Figure 2. Representative 2-DE maps comparing the soluble proteomes of Alexandrium catenella ACT03 grown under exposure to zinc 6,12 or $18 \mathrm{M}\left(\left[\mathrm{Zn}^{2+}\right]_{\mathrm{F}}=280,620\right.$ and $1000 \mathrm{nM}$ respectively) and control conditions. (A): Protein profiles of Alexandrium catenella ACT03 grown under exposure to zinc 6, 12 or $18 \mathrm{M}(\mathbf{B})$ : Protein profile of Alexandrium catenella ACT03 grown in control conditions. Proteins of interest are identified by their spot numbers $(\mathbf{C})$ : Names of the proteins of interest are shown with the fold differences in their expression, according to the level of zinc exposure. In black, up-regulated proteins; in grey, down-regulated proteins; D, disappeared proteins. ${ }^{* * *}$ and ${ }^{* * *}$ :proteins whose expression was different under zinc exposure, with $0.05<\mathrm{P}<0.10 ; 0.01<\mathrm{P}<0.05$ and $\mathrm{P}<0.01$, respectively

\section{2.a. Exposure to zinc $6 \mathrm{M}$}

With 6 M, 54 proteins of interest were detected $(\mathrm{P}<0.10)$. Among these differentially expressed proteins, only one protein (spot 14) was significantly up-regulated (its identification failed), whereas 12 proteins were significantly down-regulated (Figures $2 \mathrm{~B} \&$ 2C). The proteins down-regulated were involved: $(i)$ in photosynthesis for RUBISCO (spot 9), PCP (spots 4, 34, 36 and 41) and FNR (spot 8) (ii) in the response to oxidative stress for proteasome $\alpha / \beta$ subunits (spots 5, 30 and 35) and SOD (spot 25). Regarding the fold differences in expression of these proteins in comparison with control, the main result was the very strong down-regulation of SOD (spot 25) (-28.0 fold) (Figure 2C).

\section{2.b. Exposure to zinc $12 \mathrm{M}$}

With 12 M, 68 proteins of interest were detected $(\mathrm{P}<0.10)$, among which 20 proteins were significantly down-regulated, whereas one protein was significantly up-regulated (not recognized in the protein database) (Figures 2B \& 2C). The proteins down-regulated were involved: $(i)$ in photosynthesis for RUBISCO (spots 9 and 29), PCP (spots 4, 36, 41 and 43) and FNR (spots 8, 21 and 39) (ii) in the response to oxidative stress for proteasome $\alpha$ subunit (spots 5 and 35) and SOD (spot 25) (iii) in cell signaling, activation of protein kinases and $\mathrm{Ca}^{2+}$ binding for CaM (spot 26) (iv) with the chaperones HSP 70 (spot 10), and CALR (spot 19) which is also involved in $\mathrm{Ca}^{2+}$ binding. Effect of zinc $12 \mathrm{M}$ was particularly harmful on the protein $\mathrm{CaM}$, as indicated by the maximal fold difference in its down-regulation $(-21.8$ fold) with regards to control (Figure 2C). 


\section{2.c. Exposure to zinc (18 M)}

With 18 M, 111 proteins of interest were detected $(\mathrm{P}<0.10)$, among which 25 proteins were identified (Figures 2B \& 2C). As observed for lead at the same concentration, zinc induced the disappearance of many proteins. These proteins are involved (i) in photosynthesis for RUBISCO (spots 9 and 29), FNR (spots 21 and 39) and PCP (spots $4,34,36,41,43$ and 46 ) (ii) in the response to oxidative stress for proteasome $\alpha / \beta$ subunits (spots 5, 30, 35, 37, 44 and 45, 46) and SOD (spot 25) (iii) in energy metabolism for ATPsynthase $\beta$ subunit (spot 16) (iv) take part in cell signaling, activation of protein kinases and $\mathrm{Ca}^{2+}$ binding for CaM (spot 26) (v) is the chaperone HSP 70 (spots 10 and 40) (vi) in carbohydrate metabolism for RPI (spot 28). Three proteins were significantly up-regulated (spots 1, 13 and 14), but their identification failed, or led to unknown peptide sequences. The fold differences in expression of the up- and down-regulated proteins in comparison with control, ranged between -4.4 (PCP: spot 41) and +6.8 (spot 13) fold (Figure 2C).

\section{2.d. Intercomparison of the proteomic modifications under zinc stresses}

The total number of proteins constituting the soluble proteome of A. catenella ACT03 exposed to $18 \mathrm{M}$ of zinc was significantly lower (of 32\%) than with $6 \mathrm{M}(\mathrm{P}=0.04)$, confirming the harmful effect of zinc (Figure 2A). In comparison with the other concentrations, zinc $18 \mathrm{M}$ induced the most drastic modifications in the protein expression, with the highest numbers of up- and down-regulated proteins (Figures $2 \mathrm{~B} \&$ 2C). Besides, zinc at $18 \mathrm{M}$ led to the strongest up-regulation of some proteins, reaching +6.0 (spot 1: unknown protein) and +6.8 (spot 13: unidentified protein) fold (Figure 2C). Zinc at $12 \mathrm{M}$ and $18 \mathrm{M}$ resulted in the up-regulation of a same unknown protein (spot 1) (at 18 $\mathrm{M}:+6.0$ fold; at $12 \mathrm{M}$ : +2.0 fold), whereas an unidentified protein (spot 14) was upregulated in common for zinc at $6 \mathbf{M}$ and $18 \mathrm{M}(+2.0$ fold) (Figure $2 \mathrm{C})$. Whatever the zinc concentration, RUBISCO (spot 9) disappeared and PCP (spots 36 and 41) was downregulated (Figures 2B \& 2C, Figure 2S in SuppData 2). Finally, zinc concentration had an increasing effect on the down-regulation of proteasome $\alpha$ subunit (spots 5 and 35), FNR (spots 21 and 39), SOD (spot 25), CaM (spot 26) and PCP (spots 4, 34, 41 and 43). 


\subsection{Comparison of the proteomic modifications under lead or zinc stresses}

Exposure to lead or zinc led to the up-regulation of three proteins (spots 1, 13 and 14) (Figures 1C \& 2C). However, this up-regulation, observed at a lower concentration for lead than for zinc, was stronger for lead (higher values of the fold differences). Only lead resulted in the up-regulation of five supplementary proteins (spots 12, 15, 16, 17 and 18), among which ATP-synthase $\beta$ subunit has been identified. Whatever the trace metal and its concentration, the disappearance of RUBISCO (spot 9) was observed. Similarly, zinc or lead at $12 \mathrm{M}$ and $18 \mathrm{M}$, induced disappearance of SOD (spot 25). However, higher concentrations of zinc were required to induce the disappearance of RUBISCO (spot 29). Only lead had a harmful effect on $\mathrm{BiP}$ (spot 6) and on proteasome $\beta$ subunit (spot 33), and HSP 70 (spot 40) was perturbed in expression from $6 \mathrm{M}$ for lead, against $18 \mathrm{M}$ for zinc.

\subsection{Biological functions assigned to the proteins of interest}

Biological functions have been assigned to the identified proteins of interest, in order to characterize the metabolic pathways implied in the proteomic response of A. catenella ACT03 exposed to metallic stresses (Figure 3). These biological functions are: calcium binding (CALR, CaM), carbohydrate metabolism (RPI); cell signaling and activation of protein kinases (CaM), chaperone activity (BiP, CALR,HSP 70), energy metabolism (ATP-synthase $588 \beta$ subunit; FNR), oxidative stress response (BiP, CALR, HSP 70, proteasome $\alpha / \beta$ subunits, 589 SOD), photorespiration (RUBISCO) and photosynthesis (ATP-synthase $\beta$ subunit, FNR, PCP, 590 RPI, RUBISCO). The most affected proteins were involved in the photosynthesis (from 20 591 to $37 \%$ of the proteins of interest identified, for lead at 6,12 or $18 \mathrm{M}$ and between 36 and $59250 \%$ of the proteins of interest identified for zinc at 6,12 or $18 \mathrm{M}$ ) and in the oxidative 593 stress response (from 29 to $34 \%$ for lead at 6,12 or $18 \mathrm{M}$, and between 17 and $36 \%$ for zinc 594 at 6,12 or $18 \mathrm{M})$. The metabolic pathways potentially concerned by modifications in 595 protein expression were (i) energy metabolism (8-9\% for lead at 6 and 12 M 6-9\% for zinc 596 at 6 and $18 \mathrm{M})(\mathrm{ii})$ photorespiration $(5-13 \%$ for lead at 6,12 or $18 \mathrm{M} ; 4-6 \%$ for zinc at 6 , 59712 or 18 M) (iii) chaperone activity (4-8\% for lead at 6 and 12 M; $6 \%$ for zinc at 12 and $59818 \mathrm{M})(\mathrm{iv})$ calcium binding (2-4\% for lead at 12 and $18 \mathrm{M} ; 2-5 \%$ for zinc at 12 and 18 $599 \mathrm{M})$ and $(v)$ carbohydrate metabolism (3\% for lead at $12 \mathrm{M}$ and $2 \%$ for zinc $18 \mathrm{M}$ ), 600 whereas cell signaling and activation of protein kinases $(\mathrm{CaM})$ could be only perturbed in 601 response to zinc stresses (2-3\% for zinc at 12 and $18 \mathrm{M})$. 


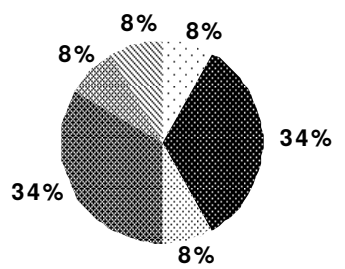

$P b 6$

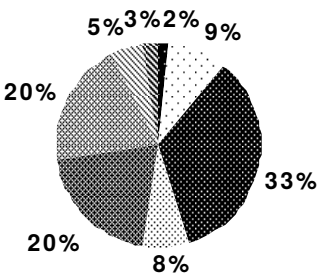

Pb 12

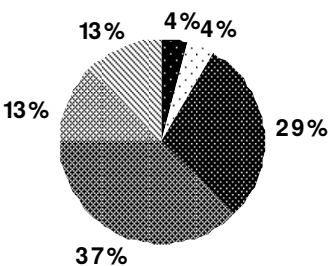

$P b 18$

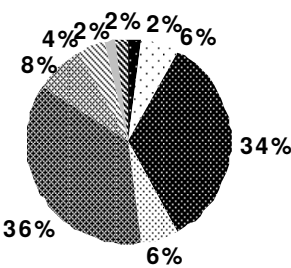

\section{Zn 6}

\section{Zn 12}

Cell signaling $\because$ Calcium binding $\because$ Chaperone

Oxidative stress $\because$ Energy metabolism

Photosynthesis Unknown $\quad$ Photorespiration N Carbohydrate metabolism

Figure 3. Biological functions assigned to the proteins of interest identified in the soluble proteome of Alexandrium catenella ACT03 exposed to lead or zinc at 6,12 or $18 \mathrm{M}$ 


\section{Discussion}

4.1. Proteomic modifications and oxidative stress response

Through down-regulation of key proteins such as SOD and proteasome $\alpha / \beta$ subunits, the oxidative stress response of A. catenella ACT03 could be a metabolic pathway particularly perturbed in response to the metallic stresses.

The induction of SOD is known to minimize oxidative cell damages among organisms living in polluted environments (Okamoto and Colepicolo, 1998). Indeed, SOD participates to the first antioxidant response to the ROS generated by metal stress (Bareen et al., 2012). In the dinoflagellate Karenia brevis, a fast induction of [Mn] SOD has been observed in response to contamination by lead at 18 M (Miller-Morey and Van Dolah, 2004). Similarly, in the marine bivalve Perna viridis, a significant expression of [Cu-Zn] SOD has been recorded, following a contamination by cadmium (Leung et al., 2011). In the dinoflagellate Gonyaulax polyedra exposed to mercury, cadmium, lead and copper, activity of SOD increased during the first day of exposure to stress, with induction of [Fe] SOD and [Mn] SOD, which was not observed for [Cu-Zn] SOD (Okamoto and Colepicolo, 1998). In the chlorophyte Chlamydomonas reinhardtii exposed to cadmium, increase in [Mn] SOD cooccurred with a decrease in [Fe] SOD (Gillet et al., 2006). A strong stimulation in the expression of [Mn] SOD was recorded at the same time as a slight decrease in expression of [Cu-Zn] SOD, in response to cadmium stress in Saccharomyces cerevisiae (Vido et al., 2001). However, lead or zinc at 12 and $18 \mathrm{M}$, systematically induced the disappearance of SOD from the soluble proteome of $A$. catenella ACT03, whereas zinc at $6 \mathrm{M}$ led to a fold difference in down-regulation reaching the very low value of -28.0 (Figures 1C \& 2C). Trace metals are known to generate oxidative stress producing ROS which damages polypeptide sequences (Stohs and Bagchi, 1995). Then, these damaged proteins are targeted for the proteasomal degradation (Delattre et al., 2005), which could explain the decreased SOD abundances measured in the soluble proteome of A. catenella ACT03, induced by metallic stresses.

The proteasome contributes to cell proteolytic activity, and thus, plays a decisive role in the oxidative stress response, by eliminating oxidized proteins, which have been beforehand targeted by ubiquitination (Flick and Kaiser, 2012). Hence, some studies reported a significant increase in abundance of ubiquitinated proteins, in cells exposed to metal stress conditions (Marzano et al., 2012). Often, increases in proteasomal degradation observed under oxidative stress conditions, correspond to prior increases in abundance of the 
646 proteasome subunits (Rodrigues et al., 2012). For instance, an over-expression of the proteasome $\alpha$ subunits, with a difference of $+\mathbf{2 . 1}$ fold, was observed in the crab Eriocheir sinensis exposed to chronic stress by cadmium (Silvestre et al., 2006). Similarly, proteasome $\alpha$ subunits were over-expressed in the macroalgae Scytosiphon gracilis and in the fish Orysias melanostigma, under copper and mercury contaminated conditions, respectively (Contreras et al., 2010; Wang et al., 2011). Nevertheless, other studies also mentioned that oxidative stress targets the proteasome itself, during reactions of glutathionylation or nitrosylation, which leads to a dysfunctioning of the proteasomal activity (Dasuri et al., 2013). In the present study, zinc or lead often induced the decrease in abundance of proteasome subunits (Figures 1C \& 2C), which could indicate such a proteasomal degradation in oxidative stress conditions.

\subsection{Proteomic modifications and photosynthesis}

Important decreases in abundances of key photosynthetic proteins (RUBISCO, PCP and FNR) have been recorded, making photosynthesis a metabolic pathway potentially and severely perturbed in response to the metallic stresses tested. These results are in agreement with many studies reporting harmful effects of trace metals on photosynthesis, as chlorophyll degradation, destruction of chloroplast ultrastructure and down-regulation of many proteins involved in the Calvin cycle (Ahsan et al., 2009; Führs et al. 2008; Gillet et al., 2006; Kieffer et al., 2008).

Concerning RUBISCO, which catalyses carboxylation of the substrate ribulose-1,5bisphosphate (RuBP) during the second step of photosynthesis (Reuman and Weber, 2006), trace metals generally decrease its abundance in the chloroplasts, as observed in the microalgae Pseudokirchneriella subcapitata exposed to chromium and palladium (Vannini et al., 2009), or in the chlorophyte Chlamydomonas reinhardtii stressed by cadmium (Gillet et al., 2006). This could result from high sensitivity of RUBISCO methionine amino acids to the metal-induced oxidative stress, which leads to methionine sulfoxide residues responsible for the targeting of proteins intended to the proteolytic degradation (Brot and Weissbach, 2000; Desimone et al., 1996; Ge et al., 2009; Stadtman et al., 2005). The oxidative degradation of the RUBISCO Binding Protein (RBP), which contributes to the RUBISCO assembly (Roy et al., 1988), as suggested in a study on P. subcapitata exposed to stress by chromium (Vannini et al., 2009), could also explain this result. Other harmful effects of metals on photosynthesis have been reported, as a significant decrease in RUBISCO activity (around 50\%) in the aquatic plant Salvinia natans submitted to metal stresses by cobalt, zinc or copper (Dhir et al., 
680 2011). This could be due, either to the harmful substitution of cation $\mathrm{Mg}^{2+}$ (organizing centre of the active sites of RUBISCO) by the metallic contaminant cations (Van Assche and Che and thiol groups in RUBISCO (Pankovic et al., 2000). The degradation, in metal stress conditions, of the RUBISCO activase involved in the RUBISCO activation (Salvucci et al., 1987), for example observed in P. subcapitata after a stress by chromium (Vannini et al., 2009), also could explain decrease in RUBISCO activity. Similarly, in the present study, RUBISCO in A. catenella ACT03 either disappeared whatever the metal tested and its concentration, or was less abundant in the soluble proteome as the metallic concentrations increased, with a stronger harmful effect of lead compared to zinc (Figures 1C \& 2C). Among the diverse consequences of this decrease in RUBISCO, a lower $\mathrm{CO}_{2}$ assimilation by the cells (Dhir et al., 2011) and a loss in efficiency of the RuBP recycling which is required by the Calvin cycle (Kieffer et al., 2008), could be expected in the cells of A. catenella ACT03.

Light energy input for photosynthesis in dinoflagellates is linked to the PCP complex (Hofmann et al., 1996). This PCP contains a carotenoid pigment, called peridinin, which is probably used as a quencher for the cells, deactivating by energy transfer, the excited state of a chemical species, and thus, acting as an antioxidant (Sigaud-Kutner et al., 2002). For instance, in the dinoflagellate Lingulodinium polyedrum, production of peridinin increased up to 60\% in response to an oxidative stress (Pinto et al., 2000). However, opposite results have been obtained with the dinoflagellate Gonyaulax polyedra for which peridinin abundance decreased after cell exposure to mercury, cadmium or copper (Okamoto et al., 2001). Even though this process reflects decrease in photosynthetic activity, the reduced peridinin concentration could also contribute to a regulation of the electron flux between the photosystems I and II, avoiding $\mathrm{O}_{2}{ }^{-}$superoxide anion formation, and consequently reducing oxidative damages (Okamoto et al., 2001). Here, PCP abundances decreased in response to most of the metallic levels (Figures 1C \& 2C), suggesting such a form of antioxidant response towards metal stress.

Similarly, the FNR enzyme, involved in the photophosphorylation step during photosynthesis, was down-regulated in the soluble proteome of A. catenella ACT03 exposed to zinc or lead. Gillet et al. ( 2006) have mentioned a toxic effect of cadmium at $150 \mathrm{M}$ on the expression of FNR by $C$. reinhardtii (fold difference: -1.7), showing the extreme FNR sensitivity to trace metals. As shown in higher plants, the FNR degradation by solubilisation can take place under oxidative conditions (Palatnik et al., 1997), which could also occur in 
the present study. Globally, these results confirm the harmful effects of metallic stresses on the photosynthesis, suggesting in fine a potential loss of energy available for the A. catenella ACT03 cells. This could be compensated by the up-regulation of some proteins, as the ATPsynthase $\beta$ subunit, as suggested below.

\subsection{Proteomic modifications and energy metabolism}

Exposure to lead at $12 \mathrm{M}$ induced the up-regulation (+16.3 fold) of ATP-synthase $\beta$ subunit (Figure 1C). Such a metal-induced up-regulation of ATP-synthase was also observed in the autotrophs: Typha angustifolia exposed to millimolar concentrations of chromium (+1.5 fold) (Bah et al., 2010), Anabaena sp. and Pteris vittata submitted to arsenic contaminations (Bona et al., 2010; Pandey et al., 2012), C. reinhardtii and lichens in response to mercury and cadmium stresses (Gillet et al., 2006; Nicolardi et al., 2012). Associated with the up-regulation of ATP-synthase, the potential increase in the ATP pool could contribute to an adaptive response of these organisms, by bringing more energy to survive under metal stress conditions (Kosova et al., 2011) and sustaining their perturbed photosynthetic activity (Bona et al., 2010). This energy could be used for detoxication processes, for example making more efficient the ATP-synthase active transport of contaminant metal cations out of the cells (Gillet et al., 2006). Moreover, ATP-synthase is known to assume peptidase function and chaperone activity, degrading abnormal and damaged proteins, or repairing them, so as to ensure the survival of the cells (Suzuki et al., 1997).

\subsection{Proteomic modifications and photorespiration}

Despite its essential contribution to photosynthesis, RUBISCO also catalyses oxygenation of the RuBP substrate during the first step of the photorespiratory pathway in autotrophs (Reumann and Weber, 2006). As a result, down-regulation of RUBISCO recorded in the present study could also suggest a weakening of photorespiration in the cells of $A$. catenella ACT03. Since photorespiration produces $\mathrm{CO}_{2}$ and $\mathrm{NH}_{3}$, and consumes $\mathrm{O}_{2}$ and ATP (Zhang et al., 2012), it is a priori considered as an energy counter-productive pathway for autotrophs, contrarily to photosynthesis. However, some studies highlight that consumption of $\mathrm{O}_{2}$ and ATP associated with photorespiration could contribute to the protection of photosynthetic organisms living in oxidative conditions (Wingler et al., 2000). As a result, in regards to photosynthesis, the photorespiratory pathway would be used by stressed autotrophs as wells of energy avoiding the hyper-reduction of the photosynthetic chain of electron transport (Wingler et al., 2000). In addition, the photorespiratory pathway 
748 leads to metabolites as glycine amino acid which is used in the biosynthesis of glutathion involved in the cellular response to oxidative stress (Noctor et al., 1999).

\subsection{Proteomic modifications and chaperone activity}

In A. catenella ACT03, lead at 6 and 12 M, and zinc at 12 and 18 M, perturbed expression of diverse chaperones belonging to the HSPs 70 family, for example BiP, also called "heat shock $70 \mathrm{kDa}$ protein 5 (HSPA5)" (Figures 1C \& 2C). These results are in accordance with those reported for Phanerochaete chrysosporium exposed to cadmium or copper at $50 \mathrm{M}$, in which abundances in HSP 20 were reduced from 70 to 80\% (Ozcan et al., 2007). Similarly, in the Sydney Rock oysters, HSP 70 was the most affected protein after contamination by cadmium $\left(50 \mathrm{~g} \mathrm{~L}^{-1}\right)$, lead $\left(5 \mathrm{~g} \mathrm{~L}^{-1}\right)$ or zinc $\left(5 \mathrm{~g} \mathrm{~L}^{-1}\right)$ (Thompson et al., 2012), whereas in the soya beans, HSP 70 abundances were four times lower under cadmium stress (Hossain et al., 2012). Besides, it is known that regulation in HSP expression is metal and concentration depending, as observed for HSP 90 in human lung cells, which was downregulated by cadmium, nickel and chromium, and up-regulated by arsenic (Andrew et al., 2003), and for HSP 22 in Argopectens irradians which decreased in response to stress by cadmium at $200 \mathrm{~g} \mathrm{~L}^{-1}$, while it was over-expressed in this bivalve exposed to cadmium at $100 \mathrm{~g} \mathrm{~L}^{-1}$ (Leung et al., 2011).

Heat shock proteins (HSPs) represent up to $2 \%$ of the cellular proteins (Gao et al., 2007). These chaperones are known to (i) help protein maturation and folding, optimizing their metabolic functionalities (Beere, 2005) (ii) avoid protein aggregation and ensuring protein membrane transport (Hossain et al., 2012). On the other hand, HSPs take part to the response to many environmental stresses, which explains increases in their abundances observed after exposure to extreme temperatures, UV, trace metals, and as a result, their use as general biomarkers under stress conditions (Timperio et al., 2008; Venn et al., 2009). During stresses, HSPs are required to $(i)$ target the damaged polypeptides so as to allow their subsequent proteasomal degradation (ii) maintain the less damaged polypeptides in their folded conformation so as to avoid their proteasomal degradation, and then, to repair and reactivate them (Miller-Morey and Van Dolah, 2004). Consequently, recovery of the cellular metabolic processes after stress is generally associated with an increase in HSP abundances (Thompson et al., 2012). For example, studies have mentioned that exposure of the dinoflagellate Karenia brevis to lead at 18 M, induced the up-regulation of HSP 60 (MillerMorey and Van Dolah, 2004), whereas HSP 70 was up-regulated in marine macroalgae and aquatic plants exposed to cadmium (Ireland et al., 2004). 
In the present study, the chaperone calreticulin was down-regulated by the metallic stresses tested (Figures 1C \& 2C). CALR is known as an endoplasmic reticulum (ER) molecular chaperone, and an ubiquitous multifunctional calcium-binding protein (Ryu et al., 2012). Calreticulin is needed in $\mathrm{Ca}^{2+}$ buffering and in quality control processes during protein synthesis and folding, in particular during refolding of misfolded proteins and ER stress responses (Leung et al., 2011). In addition to bind $\mathrm{Ca}^{2+}$, CALR would also be able to bind $\mathrm{Zn}^{2+}$ (Michalak et al., 1992), and requires zinc for its interaction with the ERp57 thiol oxidoreductase (Leach et al., 2002). Studies showed evidence that cadmium stress induced a calreticulin up-regulation in hepatopancreas of Perna viridis (Leung et al., 2011), and in leafs of Phytolacca americana (Zhao et al., 2011). Thus, it has been suggested that elevated levels of CALR could serve to protect the cells against cadmium cytoxicity (Zhao et al., 2011). The metal stress inducing ER stress, the resulting misfolded proteins would need the up-regulation of ER chaperone, like calreticulin, to be refolded (Leung et al., 2011).

\subsection{Proteomic modifications and carbohydrate metabolism}

Carbohydrate metabolism could also be perturbed in A. catenella ACT03 exposed to metal stresses, due to down-regulation of the ribose-5-phosphate isomerase (RPI), which catalyses the interconversion of Ru5P (or R5P) into R5P (or Ru5P) during ( $i$ ) the Calvin cycle (photosynthesis), in the penultimate step leading to final regeneration of RuBP (ii) the pentose phosphate pathway, in its non oxidative second phase (Zhang et al., 2003). This modification in RPI expression in the soluble proteome of A. catenella ACT03 was observed in response to contaminations by lead at $12 \mathrm{M}$ and by zinc at $18 \mathrm{M}$. This result agrees with the decrease in abundance also reported for RPI in: poplar leaves exposed at cadmium $20 \mathrm{M}$, C. reinhardtii stressed by cadmium at $150 \mathrm{M}$ (fold difference: -1.9), tomato roots in response to contamination by aluminium at 20 M (Gillet et al., 2006; Kieffer et al., 2008; Zhou et al., 2009), confirming the harmful effects of trace metals.

\subsection{Proteomic modifications and cellular signalling/activation of protein kinases}

In the present study, calmodulin was down-regulated after exposure to zinc at 12 M (-21.8 fold), to finally disappear at zinc $18 \mathrm{M}$. Thanks to the formation of a complex with $\mathrm{Ca}^{2+}, \mathrm{CaM}$ is activated to take part in cellular signaling and regulate activity of proteins called "CaM kinases", with which it interacts (Alves et al., 2010; Stefan et al., 2008). Indeed, kinases are known to regulate activity of transcription factors, which trigger or repress the ADN transcription rate into proteins (Mittler, 2002). More generally, kinases stimulate 
816 metabolic pathways via activation of many enzymes (ex: phosphorylase kinase involved in glycogenolysis) (Maksymiec et al., 2007). It is known that stress conditions induce a series of reactions increasing the $\mathrm{Ca}^{2+}$ levels, which induce CaM kinase activation. Yet, as observed here, a CaM decrease (-3.8) was observed in the liver of sea-bream exposed to chronic stress (Alves et al., 2010). Some studies have reported a possible competition between $\mathrm{Ca}^{2+}$ and metal cations on the $\mathrm{CaM}$ binding site, as observed during germination of radish plants contaminated by $\mathrm{Cd}^{2+}$ (Rivetta et al., 1997). The trace metal binding to CaM could lead to perturbations of the cellular signaling (Clemens, 2006), through inhibition, by the $\mathrm{Ca}^{2+}$ calmodulin complex, of the CaM kinase phosphodiesterase. Taking these informations into account, the down-regulated CaM could mean that the synthesis of some proteins would be inhibited after exposure to zinc via the repression of transcription factors, which could also explain the decreases in abundance (rather than down-regulation) of many proteins of the soluble proteome of A. catenella ACT03 exposed to metallic stress conditions.

\section{Conclusion}

This study showed the harmful effects of lead or zinc on the soluble proteome of $A$. catenella ACT03, and thus potentially, on key metabolic pathways in this dinoflagellate, through down-regulation of many proteins to be considered as potential biomarkers of metal stress. However, an adaptive proteomic response could also take place in the cells, at the same time, thanks to the up-regulation of other proteins as ATP-synthase implied in production of energy, which could be used to sustain detoxification processes and cell survival in presence of the metals. This suggests that, despite the clear harmful effect of trace metals, differences in the expression of some proteins could also help to maintain the development of A. catenella ACT03 in metal-contaminated ecosystems.

\section{Acknowledgments}

This research was supported by the GdR «PHYCOTOX: Des micro-algues aux risques pour l'Homme et l'écosystème », the Conseil Général du Var (CG 83), Toulon Provence Méditerranée (TPM) and the research programme ARCUS CERES (PACA-MAE). It also benefited from the financial help of LAGUNOTOX project funded by Fondation TOTAL. 
Ahsan, N., Renaut, J., Komatsu, S., 2009. Recent developments in the application of proteomics to the analysis of plant responses to heavy metals. Proteomics 9, 2602-2621.

Alves, R.N., Cordeiro, O., Silva, T.S., Richard, N., De Vareilles, M., Marino, G., Di Marco, P., Rodrigues, P.M., Conceicao, L.E.C., 2010. Metabolic molecular indicators of chronic stress in gilthead seabream (Sparus aurata) using comparative proteomics. Aquaculture 299, 57-66.

Anderson, D.M, Alpermann, T.J., Cembella, A.D., Collos, Y., Masseret, E., Montresor, M., 2012. The globally distributed genus Alexandrium: Multifaceted roles in marine ecosystems and impacts on human health. Harmful Algae 14, 10-35.

Andrew, A.S., Warren, A.J., Barchowsky, A., Temple, K.A., Klei, L., Soucy, N.V., O'Hara, K.A., Hamilton, J.W., 2003. Genomic and proteomic profiling of responses to toxic metals in human lung cells. Environ. Health Perspect. 111, 825-35.

Bae, M.S., Cho, E.J., Choi, E.Y., Park, O.K., 2003. Analysis of the Arabidopsis nuclear proteome and its response to cold stress. Plant J. 36, 652-663.

Bah, A.M., Sun, H., Chen, F., Zhou, J., Dai, H., Zhang, G., Wu, F., 2010. Comparative proteomic analysis of Typha angustifolia leaf under chromium, cadmium and lead stress. J. Hazard Mat. 184, 191-203.

Bareen, F., Shafiq, M., Jamil, S., 2012. Role of plant growth regulators and a saprobic fungus in enhancement of metal phytoextraction potential and stress alleviation in pearl millet. J. Hazard. Mat. 237-238, 186-193.

Beere, H.M., 2005. Death versus survival: functional interaction between the apoptotic and stress-inducible heat shock protein pathways. J. Clin. Invest. 115, 2633-2639.

Bona, E., Cattaneo, C., Cesaro, P., Marsano, F., Lingua, G., Cavaletto, M., Berta, G., 2010. Proteomic analysis of Pteris vittata fronds: two arbuscular mycorrhizal fungi differentially modulate protein expression under arsenic contamination. Proteomics 10, 3811-3834.

Bravo, I., Garcès, E., Diogène, J., Fraga, S., Sampedro, N., Figueroa, R.I., 2006. Resting cysts of the toxigenic dinoflagellate genus Alexandrium in the recent sediments from the Western Mediterranean coast, including the first description of cysts of A. kutnerae and A. peruvianum. Eur. J. Phycol. 41, 3, 293-302.

Brot, N., Weissbach, H., 2000. Peptide methionine sulfoxide reductase: Biochemistry and physiological role. Pept. Sci. 55, 288-296.

Choi, Y.K., Jo, P.G., Choi, C.Y., 2008. Cadmium affects the expression of heat shock protein 90 and metallothionein mRNA in the Pacific oyster, Crassostrea gigas. Comp. Biochem. Physiol. C. Toxicol. Pharmacol. 147, 286-292.

Clemens, S., 2006. Toxic metal accumulation, responses to exposure and mechanisms of tolerance in plants. Biochimie 88, 1707-1719.

Contreras, L., Moenne, A., Guillard, F., Potin, P., Correa, J.A., 2010. Proteomic analysis and identification of copper stress-regulated proteins in the marine alga Scytosiphon gracilis (Phaeophyceae). Aquat.Toxicol. 96, 8589.

Dasuri, K., Zhang, L., Keller, J.N., 2013. Oxidative stress, neurodegeneration and the balance of protein degradation and protein synthesis. Free Rad. Bio. Med. 62, 170-185.

Daware, V., Kesavan, S., Patil, R., Natu, A., Kumar, A., Kulkarni, M., 2012. Effects of arsenite stress on growth and proteome of Klebsiella pneumoniae. J. Biotechnol. 158, 8-16.

Delattre, J., Beaudeux, J.L., Bonnefont-Rousselot, D., 2005. Radicaux libres et stress oxydant : aspects biologiques et pathologiques. Editions Lavoisier 548 p.

Desimone, M., Henke, A., Wagner, E., 1996. Oxidative stress induces partial degradation of the large subunit of ribulose 1, 5- bisphosphate carboxylase/oxygenase in isolated chloroplasts of Barley. Plant Physiol. 111, 789796.

Dhir, B., Sharmila, P., Pardha Saradhi, P., Sharma, S., Kumar, R., Mehta, D., 2011. Heavy metals induced physiological alterations in Salvinia natans. Ecotox. Environ. Saf. 74, 1678-1684.

Ferrante, M., Conti, G.O., Fiore, M., Rapisarda, V., Ledda, C., 2013. Harmful algal blooms in the mediterranean sea: effects on human health. Euromed. Biomed. J. 8, 25-34.

Fertouna-Bellakhal, M., Dhib, A., Fathalli, A., Bellakhal, M., Chome, N., Masseret, E., Laabir, M., Turki, S., Aleya, L. 2015. Alexandrium pacificum Litaker sp. nov (Group IV): Resting cyst distribution and toxin profile of vegetative cells in Bizerte Lagoon (Tunisia, Southern Mediterranean Sea). Harmful Algae 48, 69-82.

Flick, K., Kaiser, P., 2012. Protein degradation and the stress response. Sem. Cell. Dev. Biol. 2, 515-522.

Führs, H., Hartwig, M., Molina, L.E.B., Heintz, D., Dorsselaer, A.V., Braun, H.P., Horst, J.W., 2008. Early manganese-toxicity response in Vigna unguiculata L. - a proteomic and transcriptomic study. Proteomics 8 , $149-159$. 
Gao, Q., Song, L., Ni, D., Wu, L., Zhang, H., Chang, Y., 2007. cDNA cloning and mRNA expression of heat shock protein 90 gene in the haemocytes of Zhikong scallop Chlamys farreri. Comp. Biochem. Physiol. B Biochem. Mol. Biol. 147, 704-715.

Ge, C., Ding, Y., Wang, Z., Wan, D., Wang, Y., Shang, Q., Luo, S., 2009. Responses of wheat seedlings to Cd, $\mathrm{Hg}$ and trichlorobenzene stresses. J. Environ. Sci. 2, 806-813.

Gillet, S., Decottignies, P., Chardonnet, S., Le Maréchal, P. 2006. Cadmium response and redoxin targets in Chlamydomonas reinhardtii: a proteomic approach. Photosynth. Res. 89, 201-211.

Guillard, R.R.L., Ryther, J.H. 1962. Studies of marine planktonic diatoms, I. Cyclotella nana Hustedt and Detonula confervacea (Cleve) Gran. Can. J. Microbiol. 8, 229-239.

Herzi, F., Jean, N., Zhao, H., Mounier, S., Mabrouk, H.H., Sakka Hlaili, A., 2013. Copper and cadmium effects on growth and extracellular exudation of the marine toxic dinoflagellate Alexandrium catenella: 3D-fluorescence spectroscopy approach. Chemosphere 93, 1230-1239.

Herzi, F., Jean, N., Sakka Hlaili, A., Mounier, S., 2014. Three-dimensional (3D) fluorescence spectroscopy analysis of the fluorescent dissolved organic matter released by the marine toxic dinoflagellate Alexandrium catenella exposed to metal stress by zinc or lead. J. Phycol. 50, 665-674.

Hofmann, E., Wrench, P.M., Sharples, F.P., Hiller, R.G., Welte, W., Diederichs, K., 1996. Structural basis of light harvesting by carotenoids peridinin-chlorophyll-protein from Amphidinium carterae. Science 272, 17881791.

Hossain, Z., Makino, T., Komatsu, S., 2012. Proteomic study of $\beta$-aminobutyric acid-mediated cadmium stress alleviation in soybean. J. Proteomics 75, 4151-4164.

Ireland, E., Harding, S.J., Bonwick, G.A., Jones, M., Smith, C.J., Williams, J.H., 2004. Evaluation of heat shock protein 70 as a biomarker of environmental stress in Fucus serratus and Lemna minor. Biomarkers 9, 139-155.

Jean, N., Bogé, G., Jamet, J.-L., Richard, S., Jamet, D., 2005. Annual contribution of different plankton size classes to particulate dimethylsulfoniopropionate in a marine perturbed ecosystem. J. Marine Syst. 53, 235-247. Jean, N., Bogé, G., Jamet, J.-L., Jamet, D., 2006. Comparison of ß-dimethylsulfoniopropionate (DMSP) levels in two Mediterranean ecosystems with different trophic levels. Mar. Chem. 101, 190-202.

Jean, N., Dumont, E., Durrieu, G., Balliau, T., Jamet, J.-L., Personnic, S., Garnier, C., 2012. Protein expression from zooplankton communities in a metal contaminated NW mediterranean coastal ecosystem. Mar. Environ. Res. 80, 12-26.

Kieffer P., Dommes J., Hoffmann L., Hausman J.F. et Renaut J. 2008. Quantitative changes in protein expression of cadmium - exposed poplar plants. Proteomics 8: 2514-2530.

Kiliç, N.K., Stensballe, A., Otzen, D.E., Dönmez, G., 2010. Proteomic changes in response to chromium VI toxicity in Pseudomonas aeruginosa. Biores. Technol. 101, 2134-2140.

Kosová, K., Vítámvás, P., Prášil, I.T., Renaut, J., 2011. Plant proteome changes under abiotic stress. Contribution of proteomics studies to understanding plant stress response. J. Proteomics 74, 1301-1322.

Laabir, M., Collos, Y., Masseret, E., Grzebyk, D., Abadie, E., Savart, V., Sibat, M., Amzil, Z., 2013. Influence of Environmental Factors on the Paralytic Shellfish Toxin Content and Profile of Alexandrium catenella (Dinophyceae) Isolated from the Mediterranean Sea. Mar. Drugs 11, 1583-1601.

Laemmli, K. ,1970. Cleavage of structural proteins during the assembly of the bacteriophage T4. Nature 227, 680-685.

Leach, M.R., Cohen-Doyle, M.F., Thomas, D.Y., Williams, D.B., 2002. Localization of the lectin, ERp57 binding, and polypeptide binding sites of calrexin and calreticulin. J. Biol. Chem. 277, 29686-29697.

Leung, P.T.Y., Wang, Y., Mak, S.S.T., Ng, W.C., Leung, K.M.Y., 2011. Differential proteomic responses in hepatopancreas and adductor muscles of the green-lipped mussel Perna viridis to stresses induced by cadmium and hydrogen peroxide. Aquat. Toxicol. 105, 49-61.

Linares, D., Jean, N., Van Overtvelt, P., Ouidir, T., Hardouin, J., Blache, Y., Molmeret, M., 2016. The marine bacteria Shewanella frigidimarina NCIMB400 upregulates the type VI secretion system during early biofilm formation. Environ. Microbiol. Rep., 8, 1, 110-121.

Lovazzano, C., Serrano, C., Correa, J.A., Contreras-Porcia, L., 2013. Comparative analysis of peroxiredoxin activation in the brown macroalgae Scytosiphon gracilis and Lessonia nigrescens (Phaeophyceae) under copper stress. Physiol. Plant. 149, 378-388.

Lowry, O.H., Rosenbraugh, N.J., Farr, A.L., Randall, R.J., 1951. Protein measurement with the Folin Phenol Reagent. J. Biol. Chem. 193, 265-275.

Maksymiec, W., Wójcik, M., Krupa, Z., 2007. Variation in oxidative stress and photochemical activity in Arabidopsis thaliana leaves subjected to cadmium and excess copper in the presence or absence of jasmonate and ascorbate. Chemosphere 66, 421-427.

Marzano, V., Santini, S., Rossi, C., Zuccherelli, M., D'alessandro, A., Marchetti, C., Mingardi, M., Stagni, V., Barila, D., Urbani, A., 2012. Proteomic profiling of ATM kinase proficient and deficient cell lines upon blockage of proteasome activity. J. Proteomics 75, 4632-4646.

Michalak, M., Milner, R.E., Burns, K., Opas, M., 1992. Calreticulin. Bioch. J. 285, 681-692. 
966

1967

2968

\begin{tabular}{l}
3969 \\
\hline
\end{tabular}

4970

5971

6972

7973

8974

9975

10976

11977

12978

13979

14980

15981

16982

17983

18984

19985

20986

21987

22988

23989

24990

25991

26992

27993

28994

29995

30996

31997

32998

33999

341000

351001

361002

371003

381004

391005

401006

${ }^{41} 1007$

42 431008

441009

451010

461011

471012

481013

491014

501015

511016

521017

531018

541019

551020

561021

571022

581023

591024

60

61

62

63

Miller-Morey, J.S., Van Dolah, F.M., 2004. Differential responses of stress proteins, antioxidant enzymes, and photosynthetic efficiency to physiological stresses in the Florida red tide dinoflagellate, Karenia brevis. Comp. Biochem. Physiol. C Toxicol. Pharmacol. 138, 493-505.

Mittler, R., 2002. Oxidative stress, antioxidants and stress tolerance. Trends Plant Sci. 7, 405-410.

Morse, D., Fritz, L., Pappenheimer, A.M., Hastings, J.W., 1989. Properties and cellular localization of a luciferin binding protein in the bioluminescence reaction of Gonyaulax polyedra. J. Biolumin. Chemilumin. 3, 79-83.

Nicolardi, V., Cai, G., Parrotta, L., Puglia, M., Bianchi, L., Bini, L., Gaggi, C., 2012. The adaptive response of lichens to mercury exposure involves changes in the photosynthetic machinery. Environ. Poll. 160, 1-10.

Noctor, G., Arisi, A.C.M., Jouanin, L., Christine, H.F., 1999. Photorespiratory glycine enhances glutathione accumulation in both the chloroplastic and cytosolic compartments. J. Exp. Bot. 50, 1157-1167.

Okamoto, O.K., Colepicolo, P., 1998. Response of superoxide dismutase to pollutant metal stress in the marine dinoflagellate Gonyaulax polyedra. Comp. Biochem. Physiol.Part C: Pharmacol. Toxicol. Endocrinol. 119, 6773.

Okamoto, O.K., Pinto, E., LaTorre, L.R., Bechara, E.J.H., Colepicolo, P., 2001. Antioxidant modulation in response to metal-induced oxidative stress in algal chloroplasts. Arch. Environ. Contam. Toxicol. 40, 18-24.

Ozcan, S., Yildirim, V., Kaya, L., Albrecht, D., Becher, D., Hecker, M., Ozcengiz, G., 2007. Phanerochaete chrysosporium soluble proteome as a prelude for the analysis of heavy metal stress response. Proteomics 7 , 1249-1260.

Page, D., Gouble, B., Valot, B., Bouchet, J.P., Callot, C., Kretzschmar, A., Causse, M., Renard, C.M., Faurobert, M., 2010. Protective proteins are differentially expressed in tomato genotypes differing for their tolerance to low-temperaturestorage. Planta 232, 483-500.

Palatnik, J.F., Valle, E.M., Carrillo, N., 1997. Oxidative stress causes ferredoxin-NADP ${ }^{+}$reductase solubilization from the thylakoid membranes in methyl viologen-treated plants. Plant Physiol. 113, 1721-1727.

Pandey, S., Rai, R., Rai, L.C., 2012. Proteomics combines morphological, physiological and biochemical attributes to unravel the survival strategy of Anabaena sp. PCC7120 under arsenic stress. J. Proteomics 75, 921937.

Pankovic, D., Plesnicar, M., Arsenijenic-Maksimovic, I., Petrovic, N., Sakac, Z., Kastori, R., 2000. Effects of nitrogen nutrition on photosynthesis in Cd-treated sunflower plants. Ann. Bot. 86, 841-847.

Péna, G., Picot, B., 1991. Métaux traces dans les sediments d'une lagune méditerranéenne : l'étang de Thau. Oceanol. Acta, 14, 459-472.

Penna, A., Garcès, E., Vila, M., Giacobbe, M.G., Fraga, S., Lugliè, A., Bravo, I., Bertozzini, E., Vernesi, C., 2005. Alexandrium catenella (Dinophyceae), a toxic ribotype expanding in the NW Mediterranean Sea. Mar. Biol. 148, 1, 13-23.

Pinto, E., Sigaud-Kutner, T.C.S., Leitao, M.A.S., Okamoto, O.K., Morse, D., Colepicolo, P. 2000. Heavy metalinduced oxidative stress in algae. J. Phycol. 39, 1008-1018.

Poirier, I., Jean, N., Guary, J.-C., Bertrand, M., 2009. Robustness to cell disruption of heavy metal-resistant Pseudomonas fluorescens BA3SM1 isolates. Environ. Eng. Sci. 26, 1451-1457.

Reumann, S., Weber, A.P.M., 2006. Plant peroxisomes respire in the light: Some gaps of the photorespiratory $\mathrm{C}_{2}$ cycle have become filled-Others remain. Biochim. Biophys. Ac. - Mol. Cell Res. 1763, 1496-1510.

Ritter, A., Ubertini, M., Romac, S., Gaillard, F., Delage, L., Mann, A., Cock, J.M., Tonon, T., Correa, J.A., Potin, P., 2010. Copper stress proteomics highlights local adaptation of two strains of the model brown alga Ectocarpus siliculosus. Proteomics 10, 2074-2088.

Rivetta, A., Negrini, N., Cocucci, M., 1997. Involvement of $\mathrm{Ca}^{2+}$ calmodulin in $\mathrm{Cd}^{2+}$ toxicity during the early phases of radish (Raphanus sativus L.) seed germination. Plant Cell Environ. 20, 600-608.

Rodrigues, P.M., Silva, T.S., Dias, J., Jessen, F., 2012. Proteomics in aquaculture: applications and trends. J. Proteomics 75, 4325-4345.

Roy, H., Cannon, S., Gilson, M., 1988. Assembly of Rubisco from native subunits. Biochim. Biophys. Ac. 957, 323-334.

Ryu, S.Y., Hong, G.U., Kim, D.Y., Ro, J.Y., 2012. Enolase 1 and calreticulin regulate the differenciation and function of mouse mast cells. Cell Signal 24, 60-70.

Salvucci, M.E., Werneke, J.M., Ogren, W.L., Portis, A.R., 1987. Purification and species distribution of rubisco activase. Plant Physiol. 84, 930-936.

Sanders, B.M., Martin, L.S., 1991. Relationships between accumulation of a $60 \mathrm{kDa}$ stress protein and scope-forgrowth in Mytilus edulis exposed to a range of copper concentrations. Mar. Environ. Res. 31, 81-97.

Sigaud-Kutner, T.C.S., Pinto, E., Okamoto, O.K., Latorre, L.R., Colepicolo, P., 2002. Changes in superoxide dismutase activity and photosynthetic pigment content during growth of marine phytoplankters in batch cultures. Physiol. Plantarum 114, 566-571.

Silvestre, F., Dierick, J.F., Dumont, V., Dieu, M., Raes, M., Devos, P., 2006. Differential protein expression profiles in anterior gills of Eriocheir sinensis during acclimatation to cadmium. Aquat. Toxicol. 76, 46-58. 
Stadtman, E.R., Van Remmen, H., Richardson, A., Wehr, N.B., Levine, R.L. 2005. Methionine oxidation and aging. Biochimica et Biophysica Acta (BBA)-Prot. Proteomics 1703, 135-140.

Stefan, M.I., Edelstein, S.J., Le Novère N., 2008. An allosteric model of calmodulin explains differential activation of PP2B and CaMKII. Proc. Natl. Acad. Sci.USA 105, 10768-10773.

Stohs, S.J., Bagchi, D. 1995. Oxidative mechanisms in the toxicity of metal ions. Free Rad. Biol. Med. 18, 321336.

Sukalovic, V.H.T., Vuletic, M., Markovic, K., Vucinic, Z., 2011. Cell wall associated malate dehydrogenase activity from maize roots. Plant Sci. 181, 465-470.

Suzuki, C.K., Rep, M., Van Dijl, J.M., Suda, K., Grivell, L.A., Schatz, G., 1997. ATP-dependent proteases that also chaperone protein biogenesis. Trends Biochem. Sci. 22, 118-123.

Tessier, E., Garnier, C., Mullot, J.U., Lenoble, V., Arnaud, M., Raynaud, M., Mounier, S., 2011. Study of the spatial and historical distribution of sediment inorganic contamination in the Toulon Bay (France). Mar. Poll. Bull. 62, 2075 - 2086.

Thompson, E.L., Taylor, D.A., Nair, S.V., Birch, G., Haynes, P.A., Raftos, D.A., 2011. A proteomic analysis of the effects of metal contamination on Sydney Rock Oyster (Saccostrea glomerata) haemolymph. Aquat. Toxicol. 103, 241-249.

Thompson, E.L., Taylor, D.A., Nair, S.V., Birch, G., Haynes, P.A., Raftos, D.A., 2012. Proteomic discovery of biomarkers of metal contamination in Sydney Rock oysters (Saccostrea glomerata). Aquat. Toxicol. 109, 202212.

Timperio, A.M., Egidi, M.G., Zolla, L., 2008. Proteomics applied on plant abiotic stresses: role of heat shock proteins (HSP). J. Proteomics 71, 391-411.

Van Assche, F.V., Clijters, H., 1990. Effects of metals on enzyme activity in plants. Plant Cell Environ. 13, 195206.

Vannini, C., Marsoni, M., Domingo, G., Domingo, F., Biondi, S., Bracale, M., 2009. Proteomic analysis of chromate-induced modifications in Pseudokirchneriella subcapitata. Chemosphere 76, 1372-1379.

Venn, A.A., Quinn, J., Jones, R., Bodnar, A., 2009. P-glycoprotein (multi-xenobiotic resistance) and heat shock protein gene expression in the reef coral Montastraea franksi in response to environmental toxicants. Aquat. Toxicol. 93, 188-195.

Vido, K., Spector, D., Lagniel, G., Lopez, S., Toledano, M.B., Labarre, J., 2001. A proteome analysis of the cadmium response in Saccharomyces cerevisiae. J. Biol. Chem. 276, 8469-8474.

Wang, D.-Z., Lin, L., Gu, H.-F., Chan, L.L., Hong, H.-S., 2008. Comparative studies on morphology, ITS sequence and protein profile of Alexandrium tamarense and A. catenella isolated from the China Sea. Harmful Algae 7, 1, 106-113.

Wang, M., Wang, Y., Lin, L., Hong, H., Wang, D., 2011. Proteome profiles in medaka (Orysias melastigma) liver and brain experimentally exposed to acute inorganic mercury. Aquat. Toxicol. 103, 129-139.

Wingler, A., Lea, P.J., Quick, W.P., Leegood, R.C., 2000. Photorespiration: metabolic pathways and their role in stress protection. Philos. Trans. R. Soc. Lond. Biol. Sci. 355, 1517-1529.

Zhang, R.G., Andersson, C.E., Savchenko, A., Skarina, T., Evdokimova, E., Beasley, S., Arrowsmith, C.H., Edwards, A.M., Joachimiak, A., Mowbray, S.L., 2003. Structure of Escherichia coli ribose-5-phosphate isomerase: a ubiquitous enzyme of the pentose phosphate pathway and the Calvin cycle. Structure 11, 31-42.

Zhang, C., Yin, Y., Zhang, Y., Lu, Q., Wen, X., Zhu, Z., Zhang, L., Lu, C., 2012. Comparative proteomic study reveals dynamic proteome changes between superhybrid rice LYP9 and its parents at different developmental stages. J. Plant Physiol. 169, 387-398.

Zhou, S., Sauvé, R., Thannhauser, T.W., 2009. Proteome changes induced by aluminium stress in tomato roots. J. Exp. Bot. 60, 1849-1857.

Zou, H.-X., Pang, Q.-Y., Zhang, A.-Q., Lin, L.-D., Li, N., Yan, X.-F., 2015. Excess copper induced proteomic changes in the marine brown algae Sargassum fusiforme. Ecotox. Environ. Safe. 111, 271-280. 
Supplementary Material
Click here to download Supplementary Material: SuppData 2._doc

Supplementary Material
Click here to download Supplementary Material: SuppData 2._doc 


\section{Highlight 1:}

Soluble proteome expressed by the invasive neurotoxic dinoflagellate Alexandrium catenella strain ACT03 grown under control and trace metal conditions (lead or zinc at 6, 12 and 18 M) was studied thanks to two-dimensional electrophoresis (2-DE).

\section{Highlight 2:}

Zinc $(6,12$ and $18 \mathrm{M})$ significantly decreased the total number of proteins constituting the soluble proteome.

\section{Highlight 3:}

Exposures to trace metal led to down-regulation of most proteins constituting the soluble proteome.

\section{Highlight 4:}

The down-regulated proteins of the soluble proteome were above all involved in the photosynthesis (RUBISCO; FNR; PCP) and in the oxidative stress response (SOD; proteasome $\alpha / \beta$ subunits).

\section{Highlight 5:}

The up-regulation of some proteins like ATP-synthase $\beta$ subunit $(+16.3$ fold in response to contamination by lead at $12 \mathrm{M}$ ) suggests a proteomic adaptive response, may be contributing to the tolerance of $A$. catenella ACT03 in trace metal-contaminated ecosystems. 